\title{
Judíos extranjeros en el reino de Valencia durante la Baja Edad Media
}

José Hinojosa Montalvo*

Universidad de Alicante

Durante la Baja Edad Media la ciudad de Valencia se convirtió en un importante emporio mercantil, lo que propició que a ella acudieran a negociar judíos extranjeros. Era un comercio que, además de la vía terrestre, utilizaba la vía marítima, a pesar de los riesgos de la piratería. Ellos y sus mercancías venían protegidos por un salvoconducto del baile general del reino. En sus contactos comerciales fue importante el papel de los conversos valencianos. Además de los judíos portugueses, de los que me ocupé en otro estudio, predominaban los norteafricanos, a los que se añadían los del sultanato de Granada, islas del Mediterráneo (Cerdeña, Sicilia y Malta), Provenza y Alemania. Se incluye una lista de estos judíos mencionados en fuentes valencianas, y un documento inédito que ilustra la actividad de un judío portugués en Valencia.

Palabras Clave: historia de los judíos; Corona de Aragón; siglo XV; comercio; Magreb.

Foreign Jews in the Kingdom of Valencia in the Late Middle Ages.-During the Late Middle Ages, Valencia became an important business centre, where foreign Jews arrived to the city to trade. It was a commerce that, apart from the land route, preferably used the seaway, even though of the risks of piracy. They and their goods came protected by a safe-conduct from the general Baile of the kingdom. The role of the conversos was very important in their commercial contacts. Apart from the Portuguese Jews, which I took care of in another study, they were predominantly North Africans, others adding up from the Granadan Sultanate, the Mediterranean islands (Sardinia, Sicily and Malta), Provence and Germany. A list of these Jews documented in Valencian sources, as well as an unpublished document that illustrates the activity of a Portuguese Jew in Valencia is attached as an appendix.

KeYwords: History of the Jews; Crown of Aragon; $15^{\text {th }}$ Century; Trade; Maghreb.

Las fuentes documentales nos desvelan que nunca hubo en tierras valencianas muchos judíos extranjeros, y quizá fue la propia dispersión de noticias la que me ha llevado a interesarme por la suerte de estos judíos que venían a Valencia y otras localidades a comerciar o por asuntos familiares, básicamente, persona-

*johimon@yahoo.es 
jes que, con frecuencia, no son más que un simple nombre -mercaderes, algún embajador- y una breve noticia de su estancia en Valencia. Ya hace unos años me ocupé de la presencia en Valencia de los judíos portugueses, que fue muy intensa durante el siglo XV, por lo que ahora no vuelvo a insistir en el tema ${ }^{1}$. Por eso me voy a centrar en aquellos judíos que durante los siglos bajomedievales eran considerados como extranjeros, es decir los no pertenecientes a la Corona de Aragón. Dicha categoría también la tenían los castellanos, pero su número y la importancia de sus actividades sobrepasan el espacio de publicación asignado, por lo que centro mi atención en los judíos de los países musulmanes, los del área mediterránea y los de más allá de los Pirineos. Casi todos los datos conocidos proceden de finales del siglo XIV y siglo XV, cuando su presencia fue más intensa, consecuencia también del esplendor mercantil de Valencia, dado que la mayoría de ellos eran mercaderes.

Es importante comenzar aludiendo a los importantes lazos familiares mantenidos por los judíos de Valencia y del norte de África, pero también con los de Mallorca, isla y ciudad que actuaba como puente y escala intermedia en estas relaciones. Sin olvidar, claro está, a los conversos de la ciudad de Valencia, otro elemento clave en estas relaciones, como veremos. El punto de partida estaba en los privilegios de los reyes de Aragón favoreciendo esta inmigración ya desde época de Jaime I. Así vemos cómo el 11 de junio de 1247, el monarca concedió su guiaje y cartas de naturalización a todos los judíos que, por tierra o por mar, acudieran a establecerse en Cataluña, Mallorca y Valencia, en particular a Salomó ben Annuar, judío de Sijilmasa, en el Reino de Fez, a su mujer e hijos, y su yerno Jucef; y al judío Isaac y a su familia ${ }^{2}$. El flujo migratorio prosiguió en las siguientes centurias, en una medida imposible de precisar, pero que no ofrece dudas, a tenor de los testimonios conservados. Así el 28 de agosto de 1337 el baile general del reino escribía al justicia de Orihuela a raíz de la prisión por Domingo Lozano del judío Abrafim Robbof, de Valencia, que fue capturado por una barca armada, considerándolo como «de buena guerra» porque se decía que era berberisco, motivo por el que el propietario quería venderlo. El baile general

${ }^{1}$ El primer investigador en plantear seriamente el estudio de los judíos extranjeros en Valencia fue Leopoldo Piles Ros, en su «Judíos extranjeros en la Valencia del siglo XV», Sef 7 (1947), págs. 354-360; $\mathrm{y}$ «El dret del XX $\mathrm{XX}^{\mathrm{e}} \mathrm{XXXX}$ (Para favorecer las relaciones comerciales de los judíos norafricanos con el Reino de Valencia) (1393-1495)», Sef 44 (1984), págs. 217-282. He estudiado la actividad de los judíos portugueses en Valencia en mi «Judíos portugueses en Valencia a fines de la Edad Media», Revista de Ciéncias Históricas 10 (1995), págs. 221-234, al que ahora hay que añadir el documento publicado al final de este artículo.

${ }^{2}$ Recojo y amplío estas noticias en mi Los judíos en tierras valencianas (Valencia 1999), págs. 11-19. 
consultó a los adelantados de la judería de Valencia, quienes le dijeron que este judío era natural de Fez, y hacía tiempo que él, junto con su padre y otros hijos de aquél, habían venido a Valencia, donde vivían actualmente y contribuían en todas las imposiciones, siendo tenidos por vecinos de la aljama, por lo que se dio la orden de ponerlo en libertad ${ }^{3}$. Desconozco cuántos judíos más siguieron los pasos de Robbof y vinieron a Valencia en busca de un mejor porvenir.

Conforme avanzó el siglo XV y la situación de las juderías valencianas se estabilizó y mejoró, estos contactos personales entre ambas orillas se incrementaron. El mejor ejemplo es la judería de Játiva, que estudié con detalle. Aquí, los judíos extranjeros jugaron un decisivo papel en la reconstrucción de la aljama setabense: de Portugal, de Castilla, pero también de Granada, ya que el «apellido» Malequí de una familia nos está sugiriendo un origen malagueño, aunque no tengamos la certeza total de ello, pero las relaciones mercantiles entre judíos setabenses y Granada así parece corroborarlo.

La certeza es total cuando se trata de judíos oriundos del norte de África, estando constatada la inmigración de familias de Túnez y la actual Argelia hacia Játiva en los años centrales de la centuria. Tremecén era el punto de partida de buena parte de estos judíos, y así lo confirma el salvoconducto otorgado por el baile general del reino el 15 de febrero de 1456 a Zalmatí, a la sazón residente en Játiva, para ir a Tremecén a recoger a su familia y regresar ${ }^{4}$.

Años más tarde, en 1479, el baile expidió otro guiaje similar a favor de Maymó Faraig, también de Tremecén, que vino a instalarse en Játiva, residiendo primero en casa de Salamó Zalmatí, el cual le serviría de apoyo al comienzo de su nueva etapa vital. Estos Zalmatí se convirtieron en la familia más dinámica de la judería de Játiva, manteniendo intensos lazos comerciales con el norte de África y con sus correligionarios de Tremecén que venían a Valencia. De su elevada posición social baste decir que Maymó Zalmatich, posible cabeza del clan familiar, poseía varios cautivos, y rabí Benahem Zalmatich actúa en representación de la aljama, como uno de sus procuradores, con motivo de la expulsión en $1492^{5}$.

También en Sagunto hubo inmigrantes norteafricanos, como lo confirma el salvoconducto concedido en 1452 por el baile general del reino a David Cohén, de Berbería, residente en Sagunto, para ir a Mallorca en la nave de Joan Callou, de Mallorca, a recuperar ciertos bienes que tenía en esa ciudad y por otros asun-

${ }^{3}$ Archivo del Reino de Valencia [en adelante, ARV], Real, 611, f. 215 (28-VIII-1337, Valencia).

${ }^{4}$ ARV, Real, 705, f. ${ }^{\circ} 114$ bis-v

5 J. Hinojosa Montalvo, La judería de Xàtiva en la Edad Media (Xàtiva 1998), vol. II, docs. 396 y 401. 
tos $^{6}$; o el expedido en febrero de 1456 a Abrahim Adderí, de Orán, que iba a dicha ciudad para traerse a su mujer e hijos y residir en Sagunto?

La presencia de estos judíos extranjeros estaba totalmente controlada por el baile general del reino y sólo si contaban con el correspondiente permiso suyo podían instalarse en la ciudad de Valencia. Ello se debía a que, como consecuencia del antijudaísmo de la sociedad valenciana, en particular de sus autoridades municipales, se intentaba erradicar la presencia judía en la ciudad de Valencia. Para ello las Cortes valencianas de 1403 dieron un fuero: «que'ls juheus no puxen aturar en la ciutat de València», limitando así la permanencia temporal de los judíos en la capital del reino.

El resultado fue que todo judío de paso por Valencia, cualquiera que fuera su motivo, debía anunciar su presencia al baile general del reino y solicitar un permiso de residencia en la ciudad. Normalmente actuaba de intercesor ante la autoridad un cristiano, cuya relación con el judío solía ser de negocios o simplemente de amistad. No solía haber problemas en las concesiones de este tipo de licencias, que se daba por un plazo de algunos meses, de uno a seis, siendo lo usual dos. El área de residencia para estos judíos excluía las parroquias de Santo Tomás, San Esteban y San Andrés, donde radicó la desaparecida judería y aledaños, prohibiéndoseles igualmente estar en las casas de los conversos. De no recibir dicho salvoconducto, violaban la ley y eran objeto de una fuerte sanción, como le sucedió a Jucef Crespí y a Mossé Cohén, de Argel, en 1432, que fueron multados con 220 s. [ueldos] por desembarcar, no presentarse al baile y no llevar su guiaje ${ }^{8}$.

No era raro -al menos está documentado para las primeras décadas del siglo $\mathrm{XV}$ - que estos judíos extranjeros, cuando venían a Valencia, se hospedaran en casa de sus antiguos correligionarios, los conversos de judío, cosa normal por otra parte, aunque los acuerdos de Cortes lo prohibieran. Es el caso del judío francés maestro Samuel que en 1410 se hospedó seis meses en casa del converso Roger de Montcada'.

La concesión del salvoconducto y permiso de residencia se hacía por un plazo específico de tiempo, que solía ser de varios meses, a fin de que los judíos

${ }^{6}$ ARV, Bailía, 1151, f. ${ }^{4} 459 \mathrm{r}-\mathrm{v}$ (4-III-1452, Valencia), cf. J. Hinojosa Montalvo, The Jews of the Kingdom of Valencia. From Persecution to Expulsion, 1391-1492 (Jerusalem 1993), doc. 527, pág. 572.

${ }^{7}$ ARV, Real, 705, f. ${ }^{\circ} 114$ bis v, suelto (5-II-1456, Valencia).

${ }^{8}$ ARV, Maestre Racional, 51, f. ${ }^{\circ}$ 143v (20-IX-1432, Valencia).

${ }^{9}$ ARV, Bailía, 1219, f. ${ }^{\text {12 }}$ r (20-I-1410, Valencia). 
tuvieran tiempo de llevar a cabo sus negocios. Otras veces, el margen de tiempo que se le daba al judío era tan sólo el periodo en el que la embarcación estuviera surta en el Grao de Valencia, como sucedió con el salvoconducto dado en junio de 1475 a Durant Maxuni, de Marsella, y a Passero, de Aviñón, para que pudieran residir en la ciudad el tiempo que la galeazas florentinas hicieran escala. Si el judío necesitaba más tiempo para terminar sus negocios, la autoridad real podía conceder una prórroga de su estancia en la ciudad. Es el caso, por ejemplo, de Yacob Sabbá León, de Orán, que en 1474 fue autorizado a estar seis meses más y poder vender tres cargas de índigo que había traído ${ }^{10}$.

Para sus desplazamientos a Valencia los judíos extranjeros, además de la ruta terrestre hacia Granada o Cataluña y Provenza, utilizaban preferentemente la vía marítima, algo lógico teniendo en cuenta su procedencia. Se trataba de embarcaciones cristianas que cubrían estas rutas mediterráneas, tanto valencianas, mallorquinas, sicilianas o catalanas, como los convoyes de galeras que saliendo desde Aigues-Mortes tocaban Berbería, donde embarcaban estos judíos, para dirigirse luego a los puertos peninsulares objeto de escala, en este caso Valencia. Estas galeras son las preferidas en la segunda mitad del siglo XV, o bien la flota de galeazas florentinas que también hacía la ruta Berbería - Valencia.

Estos intercambios mercantiles en los que participaban los judíos extranjeros ofrecían numerosas interrelaciones en hombres y en productos. En el primer aspecto, los judíos extranjeros se relacionaban con sus correligionarios valencianos, en concreto los de Sagunto y Játiva, a los que se añadían los conversos de la capital del reino y mercaderes cristianos o musulmanes, valencianos o de otros reinos, en particular de Castilla. Así, Abraham Çusén vino desde Trapani a Valencia en 1419, embarcando previamente en Berbería en las galeras genovesas y trayendo seda de Almería. En cuanto a los productos sucede lo mismo, y aunque lo habitual eran las relaciones entre judíos y mercaderes conversos, podían intervenir otros. Es el caso de Magaluf Faraig de Orán, que era factor de Galcerà Martí, mercader converso de Valencia. En 1426 cargó en la nave de Antoni Redó trigo y cebada para Valencia, participando en el envío además los mercaderes mallorquines -conversos- Daniel y Rafael Pardo, y los valencianos Galip Ripoll, musulmán, y el citado Galcerà Martí ${ }^{11}$.

Alguno de estos judíos extranjeros participó también en el tráfico de esclavos, muy floreciente en la Valencia bajomedieval, como fue el caso de Angelo de Donar, judío de Palermo, que vendío a García Pelegrí, mercader, una esclava

\footnotetext{
${ }^{10}$ ARV, Bailía, 1296, f. o 61r, cf. J. Hinojosa Montalvo, «Actividades comerciales de los judíos en Valencia (1391-1492)», Saitabi 29 (1979), págs. 21-42: 35-36.

${ }^{11}$ ARV, Bailía, 1146, f. 401r.
} 
por 47 1.[ibras], además de otra esclava a Felip de Togores, sedero, por 32 1., ambas juzgadas «de buena guerra» por el baile general ${ }^{12}$.

Cabe preguntarse por la fiabilidad de los datos ofrecidos por estas fuentes de la bailía y del maestre racional, y opino que es alta, pues la misma documentación anotaba explícitamente cuando no vinieron judíos extranjeros ni mercaderías. Así, en 1448 se dice: «[...] ]en lo dit any no-y fon vengues alguns juheus ne portades mercaderies algunes de alguns juheus stranys»; o en 1449: «En lo dit any no entrà en lo dit regne juheu ni mercaderia» ${ }^{13}$. Por tanto, dejando aparte el escaso contrabando que pudiera haber, acerca del que no he encontrado noticias relativas a estos judíos, los datos que aquí ofrezco se acercarían bastante a la realidad de estos intercambios.

\section{Dificultades}

En su viaje hasta Valencia estos judíos podían encontrarse con dificultades, aunque no más que las de cualquier otro viajero, y de hecho no son muchos los incidentes documentados en los que se vieran involucrados judíos. En mayo de 1432 se produjo un robo de 300 florines y 53 gilats de plata a Abraham Abennazera, oriundo de Alguer en Cerdeña, mientras dormía en el hostal del río de la Cenia, en la parte del Reino de Valencia, pues este río era frontera con Cataluña. Parece que el autor del robo fue Joan de Santafé, converso valenciano, y ambos venían juntos desde Tortosa, contando con el apoyo de otros cómplices, contra los que pleiteó el judío. El rey intervino en enero de 1433, instando al baile general a que resolviera dicha causa, pero la maquinaria de la justicia era muy lenta, y hasta octubre de ese año el baile general no instó al baile y al justicia de Traiguera para que tomaran declaración a los hostaleros del mencionado hostal, así como a los testigos del suceso. Entre ellos figuraba Pere de Anglesí, baile de la villa catalana

${ }^{12}$ ARV, Bailía, 78, f. ${ }^{\text {o } 164 v . ~ E l ~ i m p u e s t o ~ a b o n a d o ~ f u e ~ d e ~} 3$ s. y 4 d.[ineros], cf. V. CORTÉs Alonso, La esclavitud en Valencia durante el reinado de los Reyes Católicos (Valencia 1964); J. Hinojosa Montalvo, «Tácticas de apresamiento y ventas de cautivos en la Valencia del siglo XV», Qüestions valencianes 1 (Valencia 1978), págs. 5-45; ID. «La esclavitud en Alicante a fines de la Edad Media», en Les sociétés urbaines dans la France Méridionale et la Péninsule Ibérique au Moyen Âge. Actes du Colloque de Pau, 1988 (Paris 1991), págs. 373-392; ID. «De esclavitud a la libertad en el reino de Valencia durante los siglos medievales», en De l'esclavitud a la llibertat. Esclaus i lliberts a l'Edat Mitjana. Actes del Col-loqui Internacional en Barcelona, 1999 (Barcelona 2000), págs. 431-470.

${ }^{13} \mathrm{ARV}$, Maestre Racional, 59, f. ${ }^{\circ} 207 \mathrm{r}$, y 64, f. ${ }^{2} 207 \mathrm{v}$, respectivamente. 
de Guisona y un escudero suyo llamado Berenguer Garriga, que posaban en el hostal y según Abraham presenciaron el robo, por lo que debían ser interrogados ${ }^{14}$.

Mucho más grave fue lo que le acaeció en 1465 a un judío llamado Zaull Cap de Bugía, en Berbería, que vino a la playa de Valencia con una nave de venecianos, y estando aquí fue sacado de la nave y metido a la fuerza en la carabela de Linillo. Desde Valencia fue llevado a Ibiza y vendido como cautivo, con el consentimiento del gobernador de la isla. Luis de Vera, mercader de Valencia, y Abram Pastor, judío de Sagunto, se presentaron ante el baile general del reino para interceder por el citado judío -posiblemente fueran sus amigos y contactos comerciales en estas tierras- para protestar por esta detención, afirmando que era un acto contra derecho que no debían hacer los oficiales reales, dado que su misión era proteger a los judíos que mercantilmente vienen desde Berbería, y que confían en el seguro real. El baile valenciano en su carta al lugarteniente del gobernador de Ibiza, le ruega que mantuviera retenido al judío hasta tanto se informara de cómo vino este de Berbería y porqué fue vendido como cautivo ${ }^{15}$.

El mayor peligro, sin embargo, surgió a raíz del establecimiento del tribunal de la Inquisición moderna, que tantos perjuicios causó a la economía valenciana, hasta el punto de que los convoyes de las galeras venecianas dejaron de venir a la ciudad de Valencia debido a la represión que se abatió sobre los conversos locales y el temor entre judíos y conversos que venían en estas galeras. De ello tenemos un ejemplo muy clarificador de noviembre del año 1489. Fernando II de Aragón se había enterado a través de la relación hecha por su secretario de que los inquisidores habían apresado a un judío de Túnez que vino en las galeras venecianas, aludiendo a que debía cierta suma de dinero a un tal Joan Sisa, que fue condenado por hereje. Los patrones de las galeras, así como los moros y judíos que iban en las embarcaciones pidieron al rey que se les respetara el guiaje. El baile general intentó por todos los medios conseguir la libertad del tunecino, pero los inquisidores se oponían a ello. El judío se comprometió a pagar la deuda de 30 doblas moriscas y el rey ordenó a los inquisidores su puesta en libertad bajo fianza ${ }^{16}$. Había, por tanto, un clima de inquietud e inseguridad, que en muy poco favorecía estos viajes de judíos extranjeros.

\footnotetext{
${ }^{14}$ ARV, Real, 63, f. ${ }^{\circ}$ 6v-7r (26-II-1433, Zaragoza); ARV, Bailía, 1147, f. 425v-427r.

${ }^{15}$ ARV, Bailía, 1153, f. ${ }^{\text {619v }}$ (5-VII-1465, Valencia).

${ }^{16}$ ARV, Real, 596, f. ${ }^{\text {o } 65 r}$ (24-XI-1489, Valencia).
} 


\section{Judios norteafricanos cautivos}

Las noticias acerca de judíos del norte de África cautivos resultan bastante puntuales, y con frecuencia se trata de referencias a abusos cometicos por sus captores cristianos. Existen noticias antiguas de estos esclavos judíos en el Reino de Valencia, y el 20 de julio de 1329 Alfonso IV comisionó a maestre Alatzar, médico real, y a maestre Isaac Abenaçara, judío de la casa de la reina Leonor, Vidal Bonsenyor, de Barcelona, e Isaac Abnayub, de Valencia, para que entregaran a la curia 3.800 sueldos por el rescate de nuevos judíos de Berbería que el baile general del reino había vendido a ciertas personas como cautivos y que las aljamas de sus reinos querían rescatar, en una práctica similar a la que llevaban a cabo las aljamas musulmanas. Estos destacados personajes judíos se encargarían de tasar a las aljamas como mejor creyeran, pudiendo además elegir a dos judíos que les ayudaran en tal labor ${ }^{17}$. La redención de cautivos como forma de caridad era habitual entre cristianos, musulmanes y judíos. Otras veces el judío intentaba redimirse por sus propios medios, para lo cual obtenía una licencia del baile general para ir por el reino pidiendo ayuda para su rescate, como hizo en 1408 Jacob Bengabert, judío de Tedeliz (Dellys), cautivo en Valencia.

Sin embargo, a partir de las campañas militares de Fernando II en tierras norteafricanas y la ocupación de algunas de sus plazas más emblemáticas se va a producir la llegada a Valencia de algunos cautivos judíos.

El fenómeno se produce en la primera década del siglo XVI y lo recogió Vicenta Cortés en su estudio sobre la esclavitud en la Valencia de los Reyes Católicos. Siguiendo lo que dice la mencionada autora, nos encontramos con los siguientes datos: en el año 1509 vemos a Bartolomé González, papelero, que en junio presentó ante el baile general 13 cautivos procedentes de Orán para que le fueran declarados «de buena guerra», entre los que figuraba un tal Signes, un niño de cinco años, que declaró tener padres ${ }^{18}$. También ese mes Pedro Vizcaíno presentó como cautivo a Abraham, un judío de 35 años, que era mercader entre los moros y tenía mujer y dos hijos que estaban cautivos y se volvieron cristianos. Él, por su parte, también manifestó al baile su deseo de convertirse. Otro judío se llamaba Isaac, tenía 19 años y era mercader, y confesó que sus padres y dos hermanos se habían convertido, manifestando su deseo de hacer lo mismo. El bautismo, pues, se presentaba a ojos de estos judíos cautivos como la mejor opción para poder alcanzar la libertad en un plazo no lejano.

\footnotetext{
${ }^{17}$ ACA, Cancillería, reg. 434, f. ${ }^{\text {2 } 223 r(20-V I I-1329,}$, Valencia).

${ }^{18}$ ARV, Bailía, 196, f. ${ }^{\circ}$ 157r-160r (1-VI-1509, Valencia).
} 
No sólo fue Valencia el centro receptor de estos cautivos, cuyo número debió ser alto, pues en el mes de julio de este año Antón de Murcia, hostalero del Grao de Valencia, presentó al baile general como cautivo a Pedro, judío de 18 años, que tenía a su madre y a dos tías cautivas en Alicante, ciudad donde él fue bautizado $^{19}$. Otra noticia de Alicante es de marzo de 1510, en que el baile general del reino notificaba al de Alicante que ante él había comparecido Gerona Guitart, procurador de Juan Navarro, mercader, comunicándole que a ese puerto llegó una embarcación con seis cautivos procedentes de la toma de Bugía: tres hombres y tres mujeres, y que le había solicitado el pago de los impuestos, algo que sólo podía hacer el baile general, único autorizado a legitimar las capturas. El interesado le mostró un albarán del 5 de enero de 1510 abonando los impuestos por un judío de 45 años, una judía de 25 , otra de medio año, otra de cuatro y otra de ocho, así como algunas mercaderías ${ }^{20}$.

En septiembre de 1509, Juan de San Martín, alias del Infant, vecino del Grao de Valencia, en nombre de Bartolomé Miver, presentó al baile una judía «blanca» de Orán, llamada Isabel, de 50 años de edad. Tenía dos hijos y un hijo en Tremecén. Tras su captura fue llevada a Cartagena, donde fue bautizada, y luego traída a Valencia por un mercader.

$\mathrm{Al}$ año siguiente, hay otra noticia de la presentación por Miquel Pedrós, salinero, de una esclava «blanca» de Orán, una judía de 40 años llamada María, y en diciembre de 1511 Pere Cauder, mercader de Onda, presentó al baile general del reino tres cautivos oriundos de Trípoli: Miguelito, un judío de ocho años, apresado por Juan Navarro, alguacil de la armada, que lo vendió a Cauder; y dos musulmanas, Fátima y Mariem, de 30 años, apresadas en la mezquita ${ }^{21}$.

\section{LOS JUDÍOS Y EL COMERCIO CON EL NORTE DE ÁFRICA}

Fue en la Baja Edad Media cuando los intercambios mercantiles entre la orilla valenciana del Mediterráneo y la norteafricana se hicieron más regulares e intensas, enmarcadas dentro de las líneas globales de las relaciones de la Co-

\footnotetext{
${ }^{19}$ J. Hinojosa Montalvo, «Alicante: polo de crecimiento en el tránsito de los siglos XV al XVI», en El Mediterráneo Europeo occidental y las ciudades en el tránsito de los siglos XV al XVI (Valencia 1994), vol. 1, págs. 71-108; cf. Cortés Alonso, La esclavitud en Valencia, n. 1015.

${ }^{20}$ ARV, Bailía, 196, f. ${ }^{\circ}$ 322v-323r (23-III-1510, Valencia); cf. CoRTÉs Alonso, La esclavitud en Valencia, n. ${ }^{\circ} 1120$.

${ }^{21}$ ARV, Bailía, 197, f. 29 r y 52v-53r (4-XII-1510 y 31-XII-1511, Valencia), cf. CORTÉs Alonso, La esclavitud en Valencia, n. ${ }^{\circ} 1250$.
} 
rona de Aragón con los principados y sultanatos musulmanes del Magreb, tema del que hay abundante bibliografía ${ }^{22}$. En estos intercambios el protagonismo lo tuvieron musulmanes y cristianos del reino de Valencia, y en menor medida los judíos, lo que ha hecho que los estudios sobre estas actividades se hayan centrado en estas minorías ${ }^{23}$. No cabe duda de que los violentos sucesos de julio de 1391, que tan nefastas consecuencias tuvieron para las juderías de Barcelona, Mallorca y Valencia, repercutieron negativamente en las actividades mercantiles de musulmanes y judíos de Valencia en el comercio con el Magreb, como consecuencia de las muertes, huidas y conversiones de muchos judíos, además de la ruina económica de otros $y$, en consecuencia, del patrimonio real.

Para recuperar el pulso socio-económico de judíos y conversos, Juan I elaboró una serie de proyectos, que tuvieron mejor o peor fortuna, como fue el fracasado intento de reactivar la aljama judía de Valencia. O el de favorecer la actividad mercantil de aquellos judíos que se habían trasladado desde Valencia, Barcelona y Mallorca al norte de África, además de los allí residentes ${ }^{24}$.

Desconocemos la fecha exacta del privilegio dado por Juan I para Valencia, pero sabemos que también lo dio para Mallorca y que Martín I ratificó el 19 de agosto de 1397, y en un guiaje concedido en 1393 se dice que lo fue en virtud de los capítulos firmados por orden del rey entre el baile general del reino, en su nombre, y Pere de Muncada, en el de los conversos de Valencia y los judíos habitantes en Berbería. Los salvoconductos concedidos por el baile general a judíos norteafricanos siempre aluden a dicho guiaje real: «[...] com lo senyor

${ }^{22}$ Entre la que podemos citar Ch.-E. DufourcQ, L'expansió catalana a la Mediterrània occidental. Segles XIII X XIV (Barcelona 1969); ID., «Liaisons maritimes et commerce catalans, majorquins et valenciens avec le Maghrib, du XIII ${ }^{\mathrm{e}}$ au XV ${ }^{\mathrm{e}}$ siècles», Cuadernos de Historia Económica de Cataluña 20 (1979), págs. 109-118; J. GuIRAL, «Les relations comerciales du Royaume de Valence avec la Berbérie au XVe siècles», Mélanges de la Casa de Velázquez 10 (1974), págs. 99-131; Mª D. LÓPEZ PÉREZ, «Las relaciones diplomáticas y comerciales entre la Corona de Aragón y los estados norteafricanos durante la Baja Edad Media», Anuario de Estudios Medievales 20 (1990), págs. 149169; EAD., «Los operadores magrebíes en la Corona de Aragón a finales del trescientos y principios del cuatrocientos; las actividades mercantiles de judíos y musulmanes norteafricanos», en XIV Congresso di Storia della Corona d'Aragona (Sassari 1996), vol. 3, págs. 557-572; EAD., La Corona de Aragón y el Magreb en el siglo XIV (1331-1410) (Barcelona 1995).

${ }^{23}$ J. GuIraL, «L'aportació de les comunitats jueva i musulmana al comerç marítim de València al segle XV», Afers 5/6 (1987), págs. 33-46; J. Bordes, E. SANZ, «El protagonismo mudéjar en el comercio entre Valencia y el norte de África. El siglo xv: intercambio de culturas», en VIII Simposio Internacional de Mudejarismo. Actas (Teruel 2002), vol. 1, págs. 275-281.

${ }^{24} \mathrm{M}^{\mathrm{a}}$. D. LóPEZ PÉREZ, «El pogrom de 1391 en Mallorca y su repercusión en los intercambios comerciales con el Magreb», en Actes. Ir. Col.loqui d'història dels jueus a la Corona d'Aragó (Lleida 1991), págs. 239-260. 
rey En Johan, de loable recordació, hajets guiats e assegurats en sa bona fe reyal tots e qualsevol juheus habitants en les parts de Barberia que mercantivólment vendran a qualsevol ciutats, viles o lochs de la terra e senyoria del dit senyor rey ab totes lurs robes, béns e mercaderies» (23 de marzo de 1423). El privilegio se hacía extensivo a los mudéjares desde el 20 de agosto de 1399. La trasgresión era duramente castigada con una fuerte multa de 2.000 florines de oro.

La principal fuente para conocer estas actividades mercantiles de los judíos norteafricanos con el Reino de Valencia se contiene en las series de coses vedades del maestre racional y de bailía en el Archivo del Reino de Valencia. Es un comercio restringido a unos productos muy específicos, por cuya exportación se abonaba el correspondiente derecho al baile general del reino, y aunque no son representativos de los intercambios comerciales con el norte de África, por el momento es la única fuente, junto con el pago del dret del $X X^{e} e X X X X^{e}$, en la que se documentan judíos norteafricanos viniendo a Valencia. El maestre racional era el funcionario encargado de rendir cuentas al monarca, entre otros asuntos fiscales, de los impuestos especiales que las mercancías norteafricanas abonaban al desembarcarse en el Grao de Valencia. Estas aparecen destacadas en los libros de cuentas dentro del epígrafe «Rúbrica de manifests de robes e mercaduries de juheus e altres de les parts de Barberia», haciéndolo por primera vez en el año 1401. Anteriormente se inscribió en el apartado «Rúbrica de composicions, remissions, absolucions, avinençes e sdeveniments», es decir un apartado general a acuerdos y sucesos varios por los que el citado funcionario realizaba variados ingresos, entre ellos, por ejemplo, el contrabando de estos productos foráneos.

La documentación que incluye este tipo de productos se inicia en 1393, año en que por primera vez se consigna este tipo de noticias, y prosigue de forma irregular durante el resto de la centuria, habiendo sido objeto de un estudio monográfico por Leopoldo Piles ${ }^{25}$. Si al principio los asientos del citado impuesto estaban relacionados exclusivamente con este comercio con el norte de África, a partir de 1414 aparecen incluídos también los judíos de Sicilia y de Málaga; desde 1418 los de Portugal, y desde 1423, los de la Corona de Castilla, de tal forma que a medida que va retrocediendo la presencia de judíos norteafricanos aumenta la de portugueses $\mathrm{y}$, sobre todo, castellanos.

A ella se añaden otras series del archivo de la bailía, en la que se alude a la concesión de guiajes o salvoconductos por el baile general a estos judíos extran-

${ }^{25}$ Hay noticias de los años 1393, 1395, 1398, 1401-1410, 1412-1419, 1422-1426, 1428 1429, 1431-1433, 1435, 1437-1440, 1444-1446, 1448-1449, 1452, 1454, 1457-1458, 1460-1471, 1473-1478, 1480, 1483-1484, 1486-1487, 1489-1492 y 1495, cf. Piles Ros, «El dret del XXe e XXXX”», págs. 217-282. 
jeros para venir a Valencia sin peligro, o noticias referentes a incidentes en los que se vieron involucrados estos judíos. Ello es normal, si tenemos en cuenta que el baile general del reino era el oficial real encargado de gestionar todos aquellos asuntos que concernían a los judíos ${ }^{26}$. Estos guiajes tenían una duración a beneplácito y dos meses después de su finalización.

Los asientos contenidos en la serie del maestre racional anotaban el nombre del mercader receptor de la mercancía en Valencia, seguido por el del comerciante judío que la enviaba o traía desde Berbería, así como la participación que cada uno de ellos tenía en la operación comercial. Tras un formulario en el que se indicaba los impuestos a pagar, los ya citados vinté y quaranté, según los productos de que se tratara, se enumeran los artículos importados, consignando su peso y el precio por el que se vendieron. De la suma total se extraía la cantidad que el judío debía abonar como impuesto, en relación siempre con su participación en el negocio, lo que se consignaba al margen del ingreso, siendo ésta la parte que ingresaba el fisco real. En algún caso, como en el año 1409, se anotó la fecha completa del día de llegada, así como el nombre del patrón y el tipo de embarcación que efectuó la travesía, pero fue una excepción.

Las noticias más antiguas que se conservan son del último cuarto del siglo XIV y a través de ellas vemos como en este comercio entre Valencia y Berbería participaban tanto cristianos como judíos y mudéjares de la morería de Valencia. Es imposible evaluar la participación de cada colectivo en este comercio por falta de fuentes seriadas. Si tuviéramos que hacerlo a partir de los guiajes otorgados por el baile general del reino, veríamos como, por ejemplo, en el año 1335/¿1395? -para el que se conserva documentación- se concedieron numerosos salvoconductos a mudéjares de todo el reino que iban a comerciar a Berbería, en tanto que la presencia cristiana fue muy reducida y la judía no existió. Pero, no lo olvidemos, se trata de un dato aislado. A partir de 1391, tras el asalto y práctica desaparición de la aljama judía de Valencia, los judíos valencianos desaparecieron de esta ruta mercantil.

A partir de ahora se produjo un cambio radical en los protagonistas judíos de estos intercambios. Por un lado, al desaparecer los judíos, convertidos en su mayoría al cristianismo, serán los conversos de Valencia -y algunos de Mallorca- los que controlen durante unas décadas estas relaciones comerciales. Todo apunta a que tras la conversión, a los antiguos judíos se les abrían amplias posibilidades en el ámbito socio-económico de Valencia. Ahora eran cristianos -al menos de nombre-, con todos sus derechos, pero a su vez, los tradicionales contactos que los judíos de la Corona de Aragón mantenían con sus correligionarios norteafricanos

${ }^{26}$ L. Piles Ros, Estudio documental sobre el Bayle General de Valencia, su autoridad y jurisdicción (Valencia 1970). 
se vieron incrementados por los movimientos de población surgidos a raíz de los motines de 1391, que tanto afectaron a las juderías de Barcelona, Mallorca y Valencia. Hay que tener presente que bastantes judíos del Reino de Valencia huyeron al norte de África, donde se instalaron y continuaron practicando sin trabas su fe, y estos judíos siguieron comerciando con Valencia a través de los conversos, tan pronto la normalidad se fue restableciendo y la Corona garantizó la regularidad y seguridad de estos intercambios.

Otro cambio importante es que la participación de estos judíos extranjeros se centró, sobre todo, en la importación de productos norteafricanos, documentándose su presencia desde 1393, en que eran los judíos mallorquines los que actuaban como intermediarios del mismo, a veces actuando fraudulentamente, como Isaac Samón, judío de Mallorca, que fue multado con 220 s. por no pagar el dret del vinté ${ }^{27}$.

La fórmula habitual utilizada por estos judíos norteafricanos era la de asociarse con un natural de la Corona de Aragón, lo que les reportaba ventajas fiscales, ya que la tasa a pagar era sólo un tercio de las mercancías, dado que el cristiano no estaba sometido a estos impuestos especiales. La participación de los judíos norteafricanos y de los mercaderes valencianos en estas operaciones comerciales era, básicamente y para cuando disponemos de datos, de dos tercios por parte del que recibía la mercancía en Valencia y el tercio restante del judío, aunque también podían ir a medias («per mitat entre ells»), o tres cuartos el mercader converso variando la participación en algunos casos según el producto

Estos mercaderes valencianos que actuaban como socios e importadores de productos norteafricanos eran, fundamentalmente, neófitos de judío, convertidos tras el motín de 1391, por lo que sus contactos mercantiles con sus antiguos correligionarios se veían facilitados por los anteriores lazos religiosos, máxime si tenemos en cuenta que en esta primera generación de conversos valencianos la instrucción religiosa cristiana que recibieron fue nula, la Iglesia no se preocupó de su adoctrinamiento y los conversos siguieron, en general, conservando prácticas asociadas a su anterior religión.

Conversos valencianos de la primera generación, en la década final del siglo XIV y comienzos del XV fueron Gabriel Ballester, Pau y Pere Maçana, Gabriel Vives y Nicolau Valldaura, destacando entre todos ellos por el mayor número de transacciones Gabriel Vives y Gabriel Ballester. Todos ellos figuraban entre los

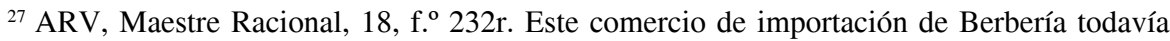
no disponía en esta fecha de un apartado propio en las cuentas del maestre racional y se incluía en la sección «varia» calificada como «multas y sucesos»: Rúbrica de composicions, remissions, absolucions, avinençes e sdeveniments. 
más destacados miembros de la oligarquía conversa y participaron activamente en las actividades mercantiles de Valencia ${ }^{28}$.

Gabriel Ballester, por ejemplo, estaba asociado en las plazas de Orán y de Honein con judíos magrebíes. En Honein su socio era Faraig ben Muça, que tenía un tercio de la participación en el negocio, siendo la de Ballester de dos tercios. Otro asociado en esta ciudad fue Magalluf ben Allón, aunque sólo tenemos constancia de una operación, en que envió en 1402 a Valencia algodón, cueros, cera, lana, pimienta de Guinea, alfombras de esparto, índigo y moneda de oro. En Orán el judío asociado a Ballester era Jucef Benluba, que también se relacionó con Pau Maçana.

Hay datos que apuntan a que en este comercio participaron también mercaderes extranjeros, como el florentino Luca de Serra, al que en 1400 multa el baile por recibir fraudulentamente mercancías de judíos de Berbería.

Además de los judíos oriundos de los distintos territorios del norte de África, también comerciaron con esta orilla meridional del Mediterráneo algunos judíos valencianos, principalmente de las juderías de Sagunto y de Játiva. De la primera de ellas podemos citar a Jacob Ardutell, que negociaba con Orán, mientras que los Salmatich o Malequí eran habituales en el comercio norteafricano en vísperas de la expulsión. También un judío de Teruel, David Faraig, participaba en este comercio, pues en julio de 1410 Pere Carbonell, mercader de Valencia, manifestó ante el baile general haber recibido de Berbería en la nave de Antoni d'Aro de Barcelona 500 cahíces y dos fanegas de trigo a través de Galcerà Martí, mercader converso de Mallorca, que participó en la empresa con dos tercios, mientras que el tercio restante fue de Faraig ${ }^{29}$. Recordemos que en Orán y Tremecén residían judíos con el apellido Faraig, quizá emparentados con los turolenses.

La participación de mudéjares valencianos en este comercio judío era mínima, y de hecho sólo he localizado tres operaciones, la primera es un caso de contrabando en 1400, cuando Xemçí, la esposa de Caat Alluxén, fue multada por haber recibido y no declarado al baile general mercaderías de Vidal Paci y otros conversos renegados valencianos en Berbería. Otro contacto corrió a cargo de Caat Ripoll y Alí Benxarnit, destacados miembros de la «burguesía» comercial de la morería de Valencia que, en 1406, recibieron una bala de algodón del judío

${ }^{28}$ J. Hinojosa Montalvo, «Los conversos de judío valencianos en el siglo xv: entre el desarraigo y la asimilación», en La península Ibérica en la Era de los Descubrimientos, 13911492. Actas de la III jornadas hispano-portuguesas de historia medieval (Sevilla 1997), vol. 1, págs. 69-98; ID., "Conversos y judaizantes en Valencia a fines de la Edad Media», Anales Valentinos, año XXII, n. ${ }^{\circ} 44$ (1996), págs. 251-274.

${ }^{29}$ ARV, Bailía, 1219, f. 116 v (30-VII-1410, Valencia). 
norteafricano Samuel Suxer ${ }^{30}$; y en 1426 Galip Ripoll, participa junto con los mercaderes conversos mallorquines Daniel y Rafael Pardo, y el también converso valenciano Galcerà Martí en la importación desde Orán de trigo y cebada enviado por Magaluf Faraig, que era factor de Martí en esta ciudad.

Los conversos valencianos, al igual que los judíos mallorquines, eran utilizados como procuradores y factores de estos judíos del norte de África, en tanto que los mercaderes valencianos utilizaban a estos últimos como sus procuradores en la orilla meridional del Mediterráneo. Es el caso de Guillem Usall, mercader de Valencia, que el 24 de octubre de 1412 nombró procurador a Samuel Nagar, judío residente en Tremecén, para realizar una intimación a Aimeric Breart, mercader que se encontraba en dicha ciudad africana ${ }^{31}$.

Acerca de las técnicas comerciales los judíos empleaban en su comercio con el norte de África las mismas que los cristianos, entre ellas el contrato de flete, el seguro marítimo o los cambios, de lo que conservamos algún ejemplo, como el seguro contratado en enero de 1427 por Guillem Ceriol sobre las mercancías que Magaluf ben Allón, judío de Honein, cargó con destino a Valencia, propiedad de Pons Dezledo ${ }^{32}$.

Otro ejemplo de estos seguros es el contratado en marzo de 1440 por Daniel Cornet, mercader de Valencia, a Jesuhé Fasvatí, por 70 libras del transporte de vino y de la persona del judío en su viaje hasta Alguer $^{33}$. En junio de 1489, Salamó Malequí, habitante en la judería de Játiva, a la sazón residente en Valencia, reconoció ante el notario que Joan de Soria, mercader, le dio al cambio 145 ducados por el seguro de las ropas cargadas en la nave patroneada por Bertomeu Vives de Denia, o por su hijo Joan Vives, en nombre del noble micer Juan de Pacis, desde que saliera de la playa de Valencia, llegando a Berbería para descargar las mercancías, prosiguiendo a Túnez para descargar ropas, y hasta su regreso a Valencia. Los 150 ducados del cambio se pagarían en el plazo de quince días a partir de la fecha en que la nave estuviera en el $\mathrm{Grao}^{34}$.

Los productos que Valencia importaba desde Berbería se movieron siempre dentro de una gama muy restringida, como puede observarse en la lista que recojo de los enviados a partir de 1395 hasta la primera década del siglo XV:

\footnotetext{
${ }^{30}$ ARV, Maestre Racional, 24, f. ${ }^{\text {166v. }}$

${ }^{31}$ ARV, prot. Vicent Saera, n. 2413 (24-X-1412, Valencia).

${ }^{32}$ ARV, prot. Vicent Saera, n. ${ }^{\circ} 2413$ (24-I-1427, Valencia).

${ }^{33}$ ARV, prot. Vicent Saera, n. ${ }^{\circ} 4391$ (17-III-1440, Valencia).

${ }^{34}$ Archivo de Protocolos del Colegio de Corpus Christi (Valencia) [en adelante, APCCCh], prot. Joan Casanova, n. ${ }^{\circ} 6168$ (4-VI-1489, Valencia).
} 
Albofor ('incienso'), 2 envíos: 2 arrobas, una cofa y un costalet.

Alforbi ('euforbio'), 2 envíos: 47 libras y un costalet.

Alquitrán, un envío: 6 jarras.

Anyines ('pieles de cordero'), dos envíos: 2 costales y 4 balas.

Astores d'espart ('esteras de esparto'), una vez: tres costales.

Bolich d'or vert, 1 envío: uno.

Boques, una vez: 2 costales.

Cera, 5 veces: 7 cargas y media, 3 costales, 5 fardos.

Cera adulterada, una vez: 13 arrobas.

Cotó ('algodón'), 16 envíos: 13 quintales y 13 arrobas)

Cueros, dos envíos: 250 unidades.

Cueros de toro y de ternera, 10 envíos: 1.318 unidades y 10 costales.

Cigrons ('garbanzos'), un envío: tres cahíces.

Çalefes, una vez.

Dátils, 12 veces: 1.289 quintales y 162 costales.

Dobles d'or, 14 veces: 1.154 doblas.

Dobles d'or morisques, 2 veces: 405 doblas.

Dobles d'or vert, una vez: 30 unidades.

Dobles tahuenes, 5 veces: 441 doblas.

Farina, un envío: un costal.

Faves, un envío: un cahíz.

Fideus, un envío: un capazo.

Forment ('trigo'), 4 veces: 686 cahíces, 3 barchillas.

Glassa ('sandarava'), 5 envíos: 2 quintales y una jarra, una carga, un carratell.

Goma, un envío: un costal

Grana, 20 veces: 5 quintales, 153 arrobas, 4 libras y 3 sacos.

Grana novella ('grana nueva'), un envío: 9 arrobas.

Indi ('índigo'), un envío: 3 cestas.

Lana de moni, una vez: un quintal y 30 arrobas.

Lana gruesa, un envío: 12 arrobas.

Lana matona, 1 vez: un saco.

Lana sutzea, un envío: una saca.

Lavor d'alquena ('labor de alheña'), 5 veces: un quintal, 100 libras, 2 costales.

Llí ('lino'), un envío: un fardo.

Manilles d'or ('manillas de oro'), dos envíos: 4 piezas.

Maçaona, una vez, 4 quintales.

Marenquo, una vez, un cántaro.

Moltons ('carneros'), sin determinar.

Nou de xarch ('nuez de malagueta'), 5 veces: 10,5 quintales, 3 arrobas, 16 libras y 7 costales. 
Panellets d'or ('panecillos de oro'), una vez: dos unidades.

Pells de guineus, una vez: 1 costal.

Perfum, 2 envíos con un costal: un quintal y 13 libras.

Plomes d'esturç ('plumas de avestruz'): 4 millares.

Pols de grana ('polvo de grana'), 4 envíos: una arroba y 20 libras.

Rótols, 106.

Senet ('adelfilla', planta medicinal): un costal y 5 arrobas.

Cueros de ternero berberisco, un envío: 300 unidades.

Tumens: cuatro.

Valdres, un envío: un costal.

No ha sido posible identificar alguno de estos productos, como tampoco saber el destino final de los mismos, aun cuando cabe pensar que la ciudad de Valencia, sus particulares y su industria, serían los principales destinatarios de tales mercaderías vendidas luego al detalle. No sabemos tampoco su posible redistribución hacia otros reinos peninsulares, lo que no parece probable si tenemos en cuenta las reducidas cantidades importadas. Otro aspecto a tener en cuenta es que sólo durante poco más de la primera década del siglo XV se especifican las mercancías traídas, ya que luego suele englobarse con la frase genérica de «robes e mercaderies», siendo imposible conocer los productos y su cantidad, aunque básicamente son los mismos arriba citados.

Se trata de un comercio en el que dominaban de forma absoluta los productos naturales y materias primas, originarios del norte de África (trigo, cebada, dátiles, cueros, etc.) o de las tierras al sur del Sahara, como las plumas de avestruz, a los que se añadirían los de Oriente, como el índigo o incienso, que desde estas áreas llegaban a las ciudades del litoral norteafricano. El predominio era de artículos alimenticios como el trigo, cebada, fideos, aunque siempre en pequeñas partidas, dado que Berbería siempre ocupó un lugar secundario en el abastecimiento frumentario de Valencia, en comparación con Castilla, Aragón o las islas del Mediterráneo bajo el manto aragonés, Sicilia y Cerdeña. El comercio de importación de trigo norteafricano a Valencia estuvo siempre controlado por mercaderes musulmanes y cristianos, como fue el caso del malagueño Cacim Brancero, que a mediados de la década de 1430 estaba especializado en la importación de grano de Tremecén ${ }^{35}$, u otros mercaderes mudéjares valencianos a fines del siglo XIV y primeras décadas del XV.

${ }^{35}$ R. Salicrú i Lluch, «Mudéjares y cristianos en el comercio con Berbería: quejas sobre favoritismo fiscal y acusaciones de colaboracionismo mudéjar, una reacción cristiana a la defensiva», en De mudéjares a moriscos: una conversión forzada. Actas del VIII Simposio Internacional de Mudejarismo (Teruel 2002), págs. 283-302: 288. 
Mas interesante era la aportación de materias primas como la grana, cueros, cera, lana, lino o algodón destinado a la industria del curtido y textil, pero tampoco esta aportación de los judíos suponía un porcentaje importante, aunque desconocemos cuál era su valor global en el comercio entre Berbería y Valencia.

Todos estos judíos norteafricanos traían doblas de oro de sus respectivos países y de distintas variedades y calidades, como se ve en la lista citada, constituyendo una de las vías de entrada del oro africano a la Corona de Aragón, lo que contribuía a alimentar los hornos de la ceca de Valencia en el siglo XV. A principios de siglo, estas doblas moriscas que circulaban por Valencia tenían un valor al cambio de $18 \mathrm{~s}$. («una dobla d'or morisqua, que val XVIII sous»). En algún caso, como veremos, las autoridades de la ceca hicieron consignar que se trataba de oro de mala calidad. El oro era importado también en forma de manillas, boliches o anecillos. El baile general percibía de estas doblas importadas la mitad del medio diezmo y su valor en el mercado valenciano a comienzos del siglo XV era de dieciocho sueldos.

Hubo algún asiento, como sucedió en el año 1401, en el que el valor de la mercancía importada se hizo en moneda musulmana, dándose a continuación su equivalente en sueldos y dineros. Entre 1454 y 1493 fueron 1.718 los doblones de oro contabilizados por la aduana valenciana, lo que supone un descenso con respecto a la primera mitad de siglo ${ }^{36}$.

En cuanto a los precios de las mercaderías, unas veces se indica su valor en arrobas o quintales, y en otras, la mayoría, tan sólo consta la suma total abonada por una determinada cantidad. Los precios pueden ser fijos, como en el caso de las monedas, pero lo habitual es que varíen en función de la calidad del producto y de las oscilaciones del mercado.

Debido al elevado valor de los intercambios procedentes de Berbería era lógico que algunos mercaderes intentaran pasarlos de contrabando, ahorrándose las tasas fiscales. En las cuentas de la administración del maestre racional encontramos datos de algunos de estos fraudes y la pena con la que fueron castigados. Así, en 1399, Isaac Samón, judío mallorquín, fue multado con 220 s. por introducir mercancías sin pagar el derecho del vinté. Al año siguiente, el mercader florentino Luca de Serra abonó una multa de 620 s. por no haber manifestado a las autoridades, ni pagado, el correspondientes derecho de las mercancías recibidas del norte de África, valoradas en 150 s., lo que hizo que el importe total de la sanción fuera de 770 sueldos $^{37}$. Ese mismo año Xemçí,

\footnotetext{
${ }^{36}$ GuIRAL, «Les relations comerciales du royaume deValence avec la Berberie», pág. 114.

${ }^{37}$ ARV, Maestre Racional, 19, f. ${ }^{\text {2 } 266 r . ~}$
} 
esposa de Caat Alluxén, de Valencia, pagó una multa de 1.980 s. por haber recibido ocultamente «robes e mercaderies» del judío Vidal Paci y otros conversos valencianos retornados al judaísmo en Berbería, bienes que el rey consideraba de su pertenencia ${ }^{38}$.

Entre los productos que estos judíos se llevaban desde Valencia al norte de África hay que citar algunos del agro valenciano, como las uvas pasas o los higos secos, el arroz o los curtientes para la industria textil, pero sobre todo serían los paños valencianos los que alimentaron estas exportaciones y encontraron en los países islámicos un mercado exterior nuevo, sobre todo desde mediados del siglo XIV.

Las embarcaciones utilizadas durante la primera década de siglo XV en el tráfico con Berbería fueron sobre todo las barcas de patrones valencianos, pero también encontramos navíos de alto porte y capacidad de carga, como eran las galeras o las galeotas, propiedad de mercaderes y marineros valencianos (Arnau Cardona, Pere Sellés, Alfonso de Valladolid, etc.) las cocas (d'En Pellicer, de Joan Ferrer, etc.) o las naves. Con todo, el predominio correspondió a las embarcaciones de pequeño y mediano calado, de menos de 50 toneladas. También hubo navíos mallorquines, que cubrían esta ruta entre ambas orillas del Mediterráneo, o catalanes, destacando en la segunda mitad de siglo. A finales de la centuria el comercio con Berbería lo monopolizaban las flotas de Venecia, Florencia y la Corona de Aragón, aunque los datos conservados apuntan a que los judíos preferían utilizar la red de galeras venecianas, en concreto el convoy de Berbería que hacía escala regular en el Grao valenciano.

Las embarcaciones solían ir armadas, dado lo peligrosa que resultaba esta ruta a causa de los piratas y corsarios de todo tipo. Aunque la documentación no ofrece, en general, datos específicos sobre las rutas seguidas en este comercio, hay que pensar que, en la mayoría de los casos, la preferida era la vía directa desde Valencia a estas ciudades norteafricanas; en otros casos, como se indica, se hacía escala en Mallorca, y existía también la ruta triangular norte de África-Granada-Valencia.

La evolución anual del tráfico generado por los judíos norteafricanos es de una variabilidad total, sin que haya unas líneas de continuidad, como ya vimos al hablar de los años en los que se registra comercio. Durante la primera década del siglo XV, los años más activos fueron 1402 y 1409 con once y diez entradas respectivamente. Ello, sin embargo, no implica una relación entre estas entradas y el volumen de las tasas percibidas, puesto que en 1399, por

${ }^{38} \mathrm{ARV}$, Maestre Racional, 19, f. ${ }^{\text {2 } 266 r .}$ 
ejemplo, con una sola operación realizada se recaudaron 570 s., mucho más que en 1405 y 1406, con varias entradas. El año 1444 el maestre racional no percibió nada del derecho del $\mathrm{XX}^{\mathrm{e}} \mathrm{y}$ del $\mathrm{XXXX}^{\mathrm{e}}$ porque no vinieron judíos a Valencia.

El impuesto del $\mathrm{XX}^{\mathrm{e}}$ y XXXX $\mathrm{XX}^{\mathrm{e}}$ se aplicaba inicialmente a los judíos del norte de África, pero a la vista de su rendimiento se fue extendiendo a todos los judíos extranjeros, incluidos los castellanos y portugueses, que desde los años veinte quedan incluidos, lo que dio pie a alguna protesta por una tasa que consideraban ilegal, como hicieron los judíos murcianos.

Los judíos que regresaban a sus hogares tras comerciar en Valencia debían abonar al baile general unos impuestos, que el 27 de agosto de 1492, una vez ya expulsados los judíos de las Coronas de Castilla y Aragón, se fijaron en $3 \mathrm{~s}$. y $4 \mathrm{~d}$., en tanto que los musulmanes abonarían $13 \mathrm{~s}$. y $4 \mathrm{~d}$. por la licencia de sus personas y bienes ${ }^{39}$.

El impuesto abonado por los mercaderes judíos del norte de África por las mercancías enviadas a Valencia recibía el nombre de vinté o dret del mig denme ('veinteava parte del medio diezmo') y se pagaba a cambio del guiaje que el monarca aragonés, a través del baile general del reino, les concedía para que pudieran introducir cualquier tipo de mercancías en sus reinos. Si se trataba de oro, plata y piedras preciosas no pagaban la veinteaba parte, sino la «mitad del mig denme, ço és lo quaranté», medida destinada a favorecer la importación de metales preciosos para las cecas de la Corona.

Con el fin de evitar el fraude, en 1409 escribía Martín I al baile general del Reino de Valencia, instándole a que ningún comerciante africano cometiera engaño, de forma que los derechos reales quedaran salvaguardados.

Entre 1399 y 1409 el valor de las mercancías enviadas desde el norte de África a Valencia por estos judíos ascendió a la nada despreciable suma de 110.606 s. y 93 d., recaudándose en concepto de impuestos, 3.923 s. y 9 d., que se reparten así anualmente: 570 s. (1399); 179 s. y 9 d. (1401); 674 s. y 9 d. (1402); 26 s. y 6 d. (1403); 176 s. y 5 d. (1405); 29 s. (1406); y 2.875 s. (1409).

Podemos concluir afirmando que se trataba de unos intercambios que jugaron un débil papel en el volumen global del comercio valenciano con el norte de África, que también fue subsidiario en líneas generales, tendencia ésta que se fue acentuando a medida que avanzaba la centuria, a tenor de la decadencia global de los contactos entre Berbería y Valencia.

${ }^{39}$ ARV, Bailía, 1160, f. ${ }^{\text {519v }}$ (27-VIII-1492, Valencia). 
Como es sabido, el término «Berbería» para los súbditos medievales del rey de Aragón comprendía la zona central del Magreb, básicamente la actual Argelia, ya que Túnez y Fez aparecen siempre bien diferenciadas en las fuentes, al ser unidades políticas bien definidas. En cambio, tras el nombre genérico de «Berbería», el historiador ignora a qué ciudad se refería el escribano: lo mismo podía ser Argel que Bugía, Orán, Honein, Tremecén, etc. Hemos respetado la división geográfica trazada por los escribanos, para los que era más importante la condición de «berberisco» que ser oriundo de una ciudad concreta, aún cuando ambas fórmulas sean compatibles.

Si bien hubo de forma esporádica judíos berberiscos comerciando anteriormente con Valencia, fue a partir de 1393 cuando la situación se regularizó en virtud de los acuerdos firmados por el baile general del reino, en nombre de Juan I, y Pere de Montcada, como representante de los judíos habitantes de Berbería, muchos de los cuales sería oriundos de la Corona de Aragón, sobre todo de Mallorca y Valencia ${ }^{40}$.

A partir de ahora, su mención en las fuentes se hace habitual, siendo Fuxén Abdulfach, un judío natural de Mallorca residente en Berbería, el primero que trajo y vendió mercaderías en Valencia: 100 doblas de oro moriscas, 39 cueros de toro, una carga y media de cera y plumas de avestruz, todo valorado en 1.520 sueldos. Por su parte Abdulfach se llevó de Valencia a Barcelona 40 jarras de aceite, 51 odres de alquitrán, una pieza de paño azul, dos capazos de alcohol, 13 jarras pequeñas de vino «judío», 4 sacas de gotzema ('espliego'), una sarria ('espuerta grande') de tártaro (utilizado en la industria textil), y tres jarras de cerámica de Manises, por valor de 2.165 s., que superaba sus importaciones desde el norte de África. En esta década final del siglo XIV tan sólo encuentro otra noticia referente a Berbería, y es la exportación en 1398 por Pere de Montcada, converso de Valencia, de 10 pares de cardas.

Comienza la primera década del siglo XV con el envío por varios judíos berberiscos, cuyos nombres no se especifican, a Pere Maçana, converso de Valencia -que participaba a medias en el negocio-, de 8 panes de cera, 5 saquitos de grana nueva y 2 de algodón, y 20 doblas tauheties. A este se añadió otro envío

${ }^{40}$ Piles no encontró el original de la concesión del privilegio a las relaciones comerciales con el Reino de Valencia, pero sí el otorgado a Mallorca (y la traslación legalizada que del mismo se hizo para la ciudad de Barcelona), pese a que la documentación (ARV, Maestre Racional y Bailía) hace referencia al mismo (véase PiLEs, «El dret del $\mathrm{XX}^{\mathrm{e}}$ e $\mathrm{XXXX}^{\mathrm{e}} »$, pág. 218). Este autor incluye un documento de 23-III-1423 que alude al salvoconducto real concedido a los judíos de Berbería que vinieran a comerciar a Valencia (ibíd., pág. 229). 
a dicho converso de un saco de grana pesando tres arrobas y cuatro libras, una cofeta de polvo de grana, y 23 çalefes.

En 1405 Hahim Zuçeins enviaba a Gabriel Vives 66 cahíces y 3 barchillas de trigo, dos costales de anyines, una saca de lana matona, 6 tinajas de alquitrán, 13 arrobas de cera, 60 libras de alquena ('alheña'), y 5 doblas moriscas de oro. Otro judío que comerció este año fue Faraig Benmuça, que envió a Gabriel Ballester, converso, una cofa de albofor (¿por alazfor, 'azafrán bastardo'?) y 97 cueros de toro y ternera. El converso y sus compañeros cristianos tenían en el negocio una participación de dos tercios del mismo. Al año siguiente fue Abraham Jacob quien remitió a Nicolau Valldaura, también converso, un costal de cera, un saco de grana y una cesta muy bella, mientras que Samuel Suxer remitía un saco de algodón a Caat Ripoll y Alí Benxarnit, mercaderes mudéjares de la capital.

En 1409 vino a Valencia el judío de Berbería -en 1410 se especifica que era de Fez- Isaac Almalé en la galera de Arnau Cardona y se trajo 54 quintales de cera, 10 costales de índigo, 4 costales de nuez de «exarch» y 450 doblas. En otro viaje en la coca de Pellicer trajo 64 costales de dátiles, 20 costales de cera, dos de grana y dos de goma y harina, y un fardo de lino. Fue un cargamento importante pues se vendió por 23.798 sueldos. Ese mismo año, David Xuxí, que vino a comerciar fue multado injustamente por el duque de Gandía por no llevar la rodela en el vestido. Esto nos indica que, tras desembarcar en el Grao valenciano, estos judíos en algunos casos se desplazaban por las comarcas en torno a la capital, en este caso los dominios del duque de Gandía, al sur de la misma, para realizar sus operaciones mercantiles, o por razones personales.

No hay más noticias de judíos calificados como «de Berbería» hasta 1413 en que varios de ellos enviaron ropas y mercancías a Gabriel Ginés, mercader de Valencia. En 1414, Jucef Ben Halgén vendió mercaderías por valor de 220 s., y en 1415 por otros 165. Este año se cita a un tal Jacob, que vendió cierto hilo de Almería, en tanto que Çelom Bennuno y Abrafim Arquet vendieron a través de su factor Gabriel Vives ropas y mercaderías valoradas en 3.800 sueldos. Ese año, la documentación denomina a Arquet, judío de Orán, y sabemos que Bennuno lo era de Honein, lo que muestra de forma clara que detrás del genérico «Berbería» se encontraba alguna de las ciudades norteafricanas a las que más adelante me refiero.

En algún caso el baile general del reino manifestó una clara política proteccionista con relación a estos judíos, favoreciendo la exportación y los ingresos fiscales de la bailía, como vemos en febrero de 1424, cuando ordena a Antoni Sexo, patrón de una nave siciliana, que antes de que algún mercader cargara mercancías en la misma, permitiera a David Almalé, a la sazón residente en 
Valencia, cargar toda la alheña que quisiera para llevársela a Alcudia u Honein, bajo la pena de 500 florines $^{41}$.

Otros judíos berberiscos que comerciaron con Valencia fueron Mordofay Baruch en 1440; Abrafim, que en 1466 trajo 80 doblas; y Jacob, que vendió drogas ese año por valor de 24 libras; Jucef vendió 25 mazos de plumas de avestruz en 1474; Abraham Adytun, 150 mazos de dichas plumas, y Magaluf 15 libras de benjuí y nueve barraganes ('abrigo de tela de lana para hombre').

En el año 1486 vinieron Israel de Cathán con grana; Daniel con ropa y mercadería; rabí Calem con barraganes y otros productos, y Alaig Çaragoçí, que vendió un cahíz de trigo. En 1491 lo hizo Hobida, que compró ropas y mercaderías para llevarse a Bugía por valor de 34 libras. El último judío berberisco documentado es Salamó, multado con 14 s. por el baile general por cargar sin permiso bizcocho en las galeras ${ }^{42}$.

Alguno de estos judíos berberiscos tenía la condición de cautivo, como fue el caso de Jacob Bengarbat, oriundo de la ciudad de Tedeliz, en Berbería, al que el baile general concedió licencia en 1408 para ir por el reino a recaudar la suma necesaria para su rescate ${ }^{43}$. En otros casos sabemos de la presencia de judíos berberiscos a través de la licencia que el baile general les concede para regresar a su país de origen (citado de forma genérica). Es el caso de la concedida en 1414 a siete judíos venidos de tierra de moros para regresar a sus casas, siendo todos ellos muy pobres, por lo que hubo que reducirles el impuesto de salida; Samuel Benjacob y Jucef Albellí en 1418; Jacob Jilicón en 1419; como impuesto de salida abonaron 22 ó 33 sueldos.

\section{Argel}

Nos quedan noticias de algunos judíos que vinieron a comerciar desde Argel a Valencia, como Jafudá Abbez, que en 1439 trajo 15 doblas a Valencia para comprar mercaderías, mientras que en 1440 Yuhué Faznán vendió 25 doblas y Jesuhé Fasvatí llevó vino a Argel. Otro judío de esta ciudad fue Abraham Leví, al que en 1467 el baile general le concedió guiaje y aplazamiento de deudas. Alguno intentó entrar clandestinamente en Valencia, como Jucef Crespí y Mossé Cohen en 1432, que iban en la galera del patrón Daniel Pardo y, sin licencia

\footnotetext{
${ }^{41}$ ARV, Bailía, 1140, f. o 18r (7-II-1424, Valencia).

${ }^{42}$ ARV, Maestre Racional, 105, f. ${ }^{\circ}$ 62r.

${ }^{43}$ ARV, Maestre Racional, 26, f. ${ }^{\circ}$ 170v.
} 
del baile general, desembarcaron en Valencia sin presentarse ante este ni pedir guiaje, por lo que «com sien enemichs del senyor rey» se les multó con 220 suel$\operatorname{dos}^{44}$. El regreso a sus lugares de origen lo hacían en embarcaciones cristianas, con licencia del baile, y no era raro que antes de llegar a Argel hicieran escala en Mallorca. Así hizo en 1444 Abraham Benizmal de Argel, que desde Valencia iba a Mallorca en la barca de Bonanat Beruich de Lloret de Mar, y desde allí a Argel en $1440^{45}$. Algunos judíos valencianos mantenían contactos familiares o personales con judíos de Argel, como se desprende del guiaje concedido el 1 de abril de 1480 por el baile general a Calom Zamero, de Sagunto, para poder regresar sin peligro, él y su mujer, desde la ciudad de Argel, a donde irían a resolver el asunto de una herencia ${ }^{46}$.

\section{Constantina}

De esta ciudad en Berbería sólo he documentado a un judío, Abraham Abenzayán, que el 7 de octubre de 1470 nombró procurador a Salomó Celmatich para recuperar de los arrendadores de los derechos del general del Reino de Valencia aquella seda que tenían en su poder ${ }^{47}$.

\section{Bugía}

La ciudad norteafricana de Bugía fue desde el siglo XI un importante centro corsario y, sobre todo, mercantil, que mantuvo activas relaciones con Valencia, aunque en este tráfico la participación de sus judíos parece que no fue muy numerosa. Entre ellos destacan los miembros de la familia Cap, como Mossé Cap, que en 1421 fue autorizado por el baile general a pasar a tierra de moros, abonando por la licencia 33 s. que entregó el mercader valenciano Joan Franch, posiblemente la persona con la que el judío mantenía contactos y actuaba como su agente en Valencia. No sabemos si se trataba del mismo que trajo en 1454 índigo en la galera veneciana ${ }^{48}$; o Zaull Cap, al que ya nos hemos referido antes,

${ }^{44}$ ARV, Maestre Racional, 51, f. ${ }^{\circ}$ 143v (20-IX-1432, Valencia).

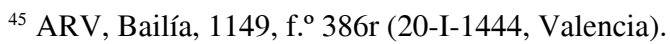

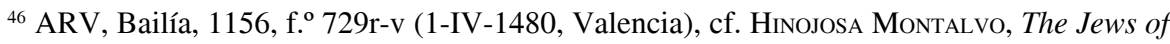
the Kingdom of Valencia, doc. 788, pág. 653.

${ }^{47}$ APCCCh, prot. Manuel d'Esparça, n. 11374 (7-X-1470, Valencia).

${ }^{48}$ ARV, Maestre Racional, 66, f. 212 r. 
que en 1465 fue apresado en la playa de Valencia y vendido como cautivo en Ibiza. Otro judío de Bugía era Vidal Sibilí, que en 1428 envió fideos a vender a Valencia. Solían utilizar para el transporte embarcaciones -galeras, naves- venecianas que desde esta ciudad norteafricana venían a Valencia.

\section{Mostaganem}

Se conservan algunos datos sobre judíos de esta localidad norteafricana, como es el nombramiento en junio de 1412 de Pere Monfort, como procurador de Ferrer Ballester, mercader, con el fin de recuperar unas mercancías de Isaac Rimós, oriundo de esa ciudad, pero a la sazón residente en Orán. Estas mercaderías se las envió Lluís Eximeno, mercader de Valencia, y según una sentencia arbitral pertenecían a Ballester ${ }^{49}$. No volvemos a encontrar judíos de Mostaganem hasta el año 1446, en que vemos a Mossé Habu y Maymó Benmuça, que habían venido a comerciar, regresando a su tierra con licencia del baile fechada el 26 de abril de $1446^{50}$.

\section{Honein}

Al Grao valenciano llegaron productos traídos por judíos desde esta localidad, como hizo en 1398 el mallorquín Magalluf Allón, que vendió en Valencia 70 arrobas de grana, 6 cargas de cera, 2.000 plumas de avestruz, y 130 doblas de oro moriscas ${ }^{51}$.

En 1401 todos los productos africanos que entraron por Valencia procedían de Honein y los trajeron Salamó Zuçén, que envió a sus socios conversos, Nicolau Valldaura y Gabriel Ballester: 63 costales de dátiles, 10 costales de cueros de toro, un costal de nuez de xarch, dos manillas de oro, 20 doblas de oro, y cuatro balas de anyines. Por su parte, Faraig Benmuça envió a Gabriel Ballester -que poseía los dos tercios del envío- 6 costales de dátiles, otros 63 de dátiles -de los cuales $3 / 4$ eran de Nicolau Valldaura-, 4 de cera, un costalet de albofor, otro de pieles de guineus, un costal de semillas de alheña, 345 doblas, 2 panes de oro pequeños, 38 cueros de toro, dos costales de boques ('cueros de macho cabrío'), y una tinaja de classa.

Este Faraig Benmuça mantuvo sus vínculos comerciales con Gabriel Balles-

\footnotetext{
${ }^{49} \mathrm{ARV}$, prot. Vicent Saera, n. ${ }^{\circ} 2413$ (7-VI-1412, Valencia).

${ }^{50} \mathrm{ARV}$, Maestre Racional, 61, f. ${ }^{\circ}$ 170v.

${ }^{51}$ ARV, Maestre Racional, 18, f. ${ }^{\circ} 228$ r.
} 
ter en 1402, trayendo a Valencia 46 costales de dátiles y uno de cera, un cajón de alforbí, un costal de labor de alquena, y dos de nuez, media arroba de senet, y un quintal y 13 libras de perfume. Este año el judío Boniva envió - a medias- a su socio converso Pau Maçana 3 costales de dátiles, pesando 6 quintales ${ }^{52}$.

En 1405 sólo hubo un envío a cargo de Salmó Sucim y Jucef Sesportes, que remitieron al converso Gabriel Vives 3 sacos de grana, pesando 9 arrobas, y un costalito de cera.

Ya no hay más noticias sobre comercio con Honein hasta 1417, aunque pudiera permanecer oculto bajo el genérico de «Berbería». Este año Salom Bennuno vendió, a través de Gabriel Vives, plumas de avestruz valoradas en 67 libras. En el año 1426 Isaac Faraig comerciaba con Valencia y en enero de 1427 tenemos noticia del seguro marítimo contratado por Guillem Ceriol sobre las mercancías que Magaluf ben Allón de Honein, cargó en esta ciudad con destino a Valencia. Más adelante, en 1437 se cita a Jucef Crespí, al que el baile general dio guiaje para venir a comerciar a Valencia ${ }^{53}$.

También algunos judíos valencianos fueron a Honein a hacer negocios, como se indica explícitamente en la licencia concedida en enero de 1418 por el baile general a Abraham Gillicón, de Sagunto, que con su mujer Mariem, sus hijos Maymona y Cadies, y Maymó Atzar pasaba a esta ciudad de Berbería, donde es posible que tuvieran parientes o amigos.

De nuevo encontramos judíos de Honein en el año 1439, en que Mahir Abenvenist y Abrafim Faraig vendieron 3 quintales de nuez del xarch y un quintal de polvo de orchilla, valorado en 120 libras.

\section{Orán}

Esta ciudad portuaria de Berbería era una de las principales terminales caravaneras, cuyos intercambios comerciales con Valencia fueron muy activos a fines de la Edad Media, sobre todo en el periodo entre 1390 y los años setenta del siglo XV. A ella debieron trasladarse algunos judíos de la Corona de Aragón, que luego siguen manteniendo vínculos comerciales con Valencia. Así, en 1395 Samuel Fatuén, judío natural de Mallorca y residente en Orán, que en 1395 envió a Valencia 300 cueros de ternero berberisco, un costal de valdres, 12 arrobas de lana gruesa, una saca de lana sucia, 115 doblas de oro moriscas (que la ceca

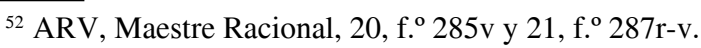

${ }^{53}$ ARV, Bailía, 1148, f. 324 r (21-II-1437, Valencia).
} 
de Valencia consideró de mal oro), 250 cueros, una arroba y media de cera, y otras 40 doblas de oro moriscas. El producto de las ventas ascendió a 3.325 sueldos. A su regreso, Fatuén se llevó a Orán 30 espuertas de higos, 7 jarras de vino, dos paños azules, dos costales de gleda, y otras 15 jarras de vino, por un valor total de 780 s., muy inferior al de las importaciones ${ }^{54}$.

No encontramos más judíos comerciando con Orán hasta 1402, en que Jucef Benluba envió al converso Gabriel Ballester -que poseía dos tercios del envíodos capazos de grana y un capazo de polvo de grana y dos arrobas y media de cera. Al también converso Pau Maçana -que participaba a medias en el envíole remitió dos sacos y una manta de algodón, dos costales de cera, 32 costales de cuero de toro y de ternero, 8 sacos de grana, más polvo de grana, un carratell de glassa, pesando dos quintales berberiscos, así como varias doblas y barritas de oro ${ }^{55}$. Estas mercancías fueron vendidas por 5.821 sueldos. En 1409 Haym Suxén trajo en la coca de Joan Ferrer, cera, algodón, grana y clasa, de las que tenía la tercera parte, vendido todo por 2.400 sueldos.

No vuelven a aparecer judíos de Orán hasta 1413, en que Abrabim Arguet (o Arquet) vendió grana por 518 sueldos y un judío de esta ciudad cuyo nombre no se indica envió ropas al converso Lluís Soler, vendidas por 64 sueldos. Arguet reaparece en 1414 vendiendo a través del mercader converso Gabriel Vives ropas y mercaderías por valor de 1.840 sueldos, así como grana que trajo en la galeota de Guillem Calbet. También vendió grana y cueros por 616 sueldos. En 1415 prosiguió los negocios con Gabriel Vives vendiendo ropas, mercaderías y cera.

En el año 1415 fue Jafudá Faraig el que vendió a través del mercader converso Lluís Soler, ropas y mercaderías valoradas en 580 sueldos. No vuelve a haber oraneses hasta 1426, cuando Magaluf Faraig, que actuaba como factor del converso Galcerà Martí, cargó trigo y cebada en la nave de Antoni Redó.

A partir de entonces la presencia de judíos de Orán se reduce haciéndose esporádica, y ya no se suelen especificar las mercancías importadas, sino la concesión del guiaje al judío que quiere ir o venir a Valencia. Así, el otorgado en 1435 a Pau Callar, converso reciente de Mallorca, que se embarcaba en Valencia para marchar a Orán, donde tenía mujer judía ${ }^{56}$. En 1437 se dio guiaje a favor de Cadacqua, judío oranés, y en 1439 Jucef Cap se trajo 18 libras de seda. En 1448 Marduf Abenabram vendió varios millares de plumas de avestruz, mientras que en 1457 Maholuf Hyalut se llevó a Orán 24 pares de cardas y

\footnotetext{
${ }^{54}$ ARV, Maestre Racional, 13, f. ${ }^{\circ} 225$ r.

${ }^{55} \mathrm{ARV}$, Maestre Racional, 21, f. ${ }^{\circ}$ 286v.

${ }^{56}$ ARV, Bailía, 1148, f. ${ }^{\circ} 118 \mathrm{r}$.
} 
una arroba de alumbre, en tanto que el judío saguntino Salamó Ardutell se llevó otros 24 pares de cardas.

En 1471 vemos de nuevo a un judío de Orán llamado Chifalla que se trajo 160 libras para comerciar, siendo el último judío documentado que -oficialmente- llega a Valencia.

\section{Tremecén}

Próxima a Orán, esta ciudad era uno de los focos más activos del comercio norteafricano, a la que llegaban los productos subsaharianos que, junto con los locales, en particular el trigo, constituían el grueso de las exportaciones hacia Valencia. A comienzos del siglo XV, Tremecén mantenía activas relaciones con Valencia, y prueba de ello es la preocupación que en 1401 mostraron las autoridades municipales valencianas ante las noticias traídas por algunos mercaderes de que los judíos de Tremecén vestían igual que los cristianos, por lo que solicitaban a Martín I, que escribiera a su homólogo de Tremecén para que este obligara a los judíos a llevar algún signo distintivo ${ }^{57}$.

El interés de las autoridades valencianas en Tremecén se centraba sobre todo en la importación de trigo, en la que participaban mercaderes mudéjares y cristianos de la ciudad. De ahí que cuando a fines de la década de 1420 las autoridades de Tremecén prohibieran la salida del grano propio, cundiera la preocupación entre los importadores valencianos. De este comercio de granos no participaron los judíos, y a lo largo de la centuria encontramos algunos judíos de esta procedencia que comerciaron con Valencia ciudad, que conocemos por los salvoconductos de regreso otorgados por el baile general a Maçot Abencazuz en 1401. Este judío había traído una alfombra, un cántaro de manteca, un capazo de fideos, y tres çalefes de cordero, valorado todo ello en 80 sueldos.

Otros judíos fueron Jucef Argem en 1419; Marzoc (o Maçot), que en 1425 había traído ropas y mercaderías para vender; Cadacqua en 1437; Jucef Gallego, que en 1457 se llevó cardas viejas a su ciudad; o Magaluf Guetdeix en 1475, que compró seda a Salamó Zalmatich, judío de Játiva, pero originario de Tremecén. Todos ellos traían «robes e mercaderies» para comerciar, sin más especificaciones, aunque alguna vez se indica el dinero traído, como las cien doblas de oro por Maymó Faraig en 1487. Solían venir en las galeras venecianas. Hubo otros judíos de esta ciudad que decidieron

${ }^{57}$ Archivo Municipal de Valencia, Lletres misives, g3-7, sin foliar (19-IX-1401). 
afincarse en el reino de Valencia, concretamente en la judería de Játiva, como ya vimos, siendo la familia Zalmatich desde 1456 y la de Maymó Faraig desde 1479 las más importantes que se instalaron, permaneciendo en Játiva hasta la expulsión de 1492.

$\mathrm{Fez}$

Aunque Fez quedaba dentro de la zona de influencia política y mercantil reservada a Castilla ya desde finales del siglo XIII con el tratado de Muluya o Monteagudo, judíos de esta ciudad y reino figuran entre los más activos que comerciaban con regularidad con Valencia durante el siglo XV. Entre ellos podemos citar a Jucef Abencaet de Fez, y a sus criados David Elxún e Isaac Borgí, que en diciembre de 1407, tras comerciar en Valencia, regresaban en la nave armada del marinero de la ciudad, Alfonso de Valladolid,. Para sus operaciones habían traído la suma de 400 doblas de oro (en 1429 se menciona a Isaac Borgí como procedente de «les parts d'Espanya», esto es, del sultanato granadino, a donde quizá hubiera trasladado su residencia. Trajo dos fardos de seda y uno de cera).

Otro judío habitual en la Valencia de comienzos del siglo XV fue David Suçí (Elsuçí, Xuxí), que en 1407 trajo 400 doblas de oro moriscas. Durante su estancia en 1409 fue multado con 15 florines por el duque de Gandía por no llevar la rodela «als pits per lo senyor rey en los furs nous declarada», lo que consideró injusto, reclamando al baile general, que consideró que los asuntos de los judíos eran de su exclusiva jurisdicción, por lo que le devolvió dicha suma ${ }^{58}$.

En el verano de 1410 David Suçí manifestaba ante el baile general 42 quintales de cera y 31 libras que trajo en la galeota de Arnau Cardona, además de otros 10 quintales y 25 libras en la galeota de Pere Sellés. En agosto recibió desde Alcudia en la nave de Salelles 140 quintales de dátiles, que vendió por 140 libras y 175 pieles de boquines vendidas en 15 libras. Sabemos que durante su estancia en Valencia compró paños a Domingo Gil, pelaire, por valor de 49 libras, que éste le reclamó el 19 de agosto ante el baile general, siendo por tanto los paños la contrapartida exportadora desde Valencia ${ }^{59}$. Además, Suçí tenía planteadas ese mismo año otras demandas ante la corte de la bailía por parte de Guillem Gal-

${ }^{58}$ ARV, Bailía, 1144, f. ${ }^{\text {o } 268 r-v}$ (20-V-1409, Valencia), cf. Hinojosa Montalvo, The Jews of the Kingdom of Valencia, doc. 285, pág. 486.

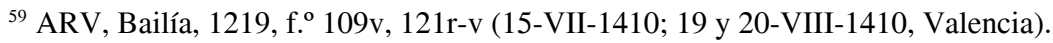


cerà y de Nicolau Julià, mercaderes valencianos a los que debía dinero ${ }^{60}$. Tantos problemas le llevaron a la cárcel ese verano, y el 4 de septiembre se obligaba ante el lugarteniente del baile general a pagar 150 libras a Simó Catreu, cambiador, por Pelegrí Cucaló, mercader de Valencia, en el plazo de diez días. Ese día Francesc Avinyó, corredor, y Ramón Berart, pelaire, salieron fiadores del judío y prometieron devolverlo vivo o muerto y pagar la deuda pendiente, bajo pena de la mitad de ella ${ }^{61}$. Es una buena muestra de todo el universo humano que se movía en el entorno de sus agitadas relaciones: mercaderes, cambistas, corredores y pelaires, a los que compraría paños para vender en Fez.

Por estos años mantuvo una intensa actividad en Valencia Isaac Almalé, que en 1409 trajo en la galera de Arnau Cardona 54 quintales de cera, 10 costales de índigo pesando 15 quintales, cuatro costales de nuez de exarch y 450 doblas, consignados a Gabriel Vives, converso de Valencia. En la coca de Pellicer trajo 124 quintales de dátiles, 29 quintales de cera, dos costales de grana, otros dos de goma y harina y un fardo de lino. En un nuevo envío hecho en la galeota de Arnau Cardona trajo y vendió 220 cueros de toro, 20 costales de dátiles, dos costales de cera, 30 quintales de cera, cuatro costales de índigo, 200 doblas de oro, 30 quintales de cera -manifestados por el mercader florentino Tomás Bellot-, 55 cahíces de trigo para el mismo mercader, 3 cahíces de cueros, un cahíz de habas y 400 doblas moriscas que trajo en la galeota de Antoni Sellés. Todos estos productos fueron vendidos por la importante suma de 38.958 sueldos.

En 1410 trajo a Valencia 155 cahíces de trigo, cuero, doblas y fideos, además de 300 cueros de toro, seis costales de grana y 500 doblas en la nave de Antoni Salelles, de Sant Feliu de Guíxols; 155 cahíces de trigo en la nave de Pere Esteve; garbanzos y habas, 6 costales de fideos y 3 de sémola, todo ello valorado en 8.800 sueldos, mientras que en 1414 vendió mercancías valoradas en 1.700 sueldos.

Otros judíos con este origen fueron Fini Suc, que se llevó paños a Fez; Elví (o Eví) Suçí o Zuçén, que estuvo comerciando en Valencia los años 1417 y $1419^{62}$; Mossé Benatorella, que en 1432 vino con mercaderías a Valencia; Mossé Almalech, oriundo de la localidad de Cazaza, en el Reino de Fez, al que en 1437 el baile general dio licencia para venir a comerciar. Alguno de estos judíos comerció con la entonces villa de Alicante, aunque sólo nos ha quedado una noticia, que es la

${ }^{60}$ ARV, Bailía, 1219, f. ${ }^{\text {7 } 78 r ~ y ~ 86 v ~(30-I V-1410, ~ V a l e n c i a) . ~ D e b i ́ a ~} 7$ libras a Guillem Galcerà, y a Nicolau Julià 44 1., 19 s. y 6 d.

${ }^{61}$ ARV, Bailía, 1219, f. $124 v$ (4-IX-1410, Valencia).

${ }^{62}$ El año 1417 el baile general del reino recibió 220 s. por la licencia dada a Eví Suçí de Fez para poder regresar a dicha ciudad desde Valencia, a donde vino con mercancías a comerciar, ARV, Maestre Racional, 37, f. ${ }^{\circ}$ 61r. 
reclamación presentada ante el baile general por Jafudá Almillos de Fez de haber pagado allí sus derechos (15 doblas) cuando fue a comerciar y que ahora le reclamaban de nuevo en Valencia ${ }^{63}$. Los productos eran similares a los de otros puntos del norte de África, y la contrapartida eran los paños valencianos.

\section{Túnez.}

Aunque Túnez no figuraba entre las principales ciudades norteafricanas con las que Valencia comerciaba, también los judíos tunecinos participaron en el siglo XV en estos débiles intercambios. La noticia más antigua es de 1410, cuando el converso valenciano Gabriel Vives reconoció ante el baile general haber recibido en la nave del mallorquín Lop Antoni dos panes de cera, un saco de lana y un carratell de fideos que le enviaba Cubram, judío de Túnez ${ }^{64}$.

Estos judíos tunecinos mantuvieron intensos lazos con los conversos mallorquines, que actuaban como intermediarios o partícipes en este comercio, como se ve en el envío hecho en 1412 por Fahim Caxarí en la nave de Joan de Sales, de Mallorca, a Francesc Pardo, mercader converso mallorquín, 180 cueros de toro, 5 fardos de cera, 1 carga de glassa, que vendió en Valencia ${ }^{65}$.

Ya no encontramos más noticias de estos judíos tunecinos hasta 1468, año desde el que estos monopolizan el escaso tráfico mercantil con el norte de África: Faraig, que se trajo 47 doblas de oro para comprar, y vendió cinco almayzars; Jucef Guadix, que vendió 9 arrobas de índigo por 24 libras; y Jacob, que vendió otros dos quintales de índigo, tres albornoces y nueve libras y una arroba de mastech.

En 1469 fueron cuatro los judíos de Túnez que comerciaron con Valencia: Abrahim, que vendió polvo de grana y tres libras de hilo de Almería; Çaat, vendió ocho albornoces gruesos; Isaac Galipapa, vendió cinco albornoces; tres libras de agalia y dos barragasses; y Jucef Guindes, que se trajo 13 libras para comprar $^{66}$.

En 1470 Jucef Guindix vendió 16 barraganes, dos albornoces y tres quintales de sebo. Por su parte el judío Papa vendió ciertos productos y, junto con Abrahim Tunicí, trajeron 20 libras y 18 sueldos para comerciar. En 1471 Jucef vendió ciertos barraganes y albornoces, prenda en la que parecen haberse especializado los judíos de Túnez.

\footnotetext{
${ }^{63}$ ARV, Bailía, 1219 (1410, Valencia).

${ }^{64}$ ARV, Bailía, 1219, f. ${ }^{135}$ v. 2-10-1410, Valencia.

${ }^{65}$ ARV, Maestre Racional, 32, f. 18 r.

${ }^{66}$ ARV, Maestre Racional 79, f. 206 r-v.
} 
En esta década, en 1476, Magaluf Gades vendió cien mazos de plumas de avestruz y 20 cargas de orchilla; en tanto que Isaac Balaix vendió cera, y Abrahim Zeptim 12 libras de rosarios negros (azabache) y 11 onzas de plumas de avestruz. Al año siguiente, Mossé Leví vendió mercancías valoradas en 600 sueldos, mientras que en 1478 Marzoch vendió cierta cantidad de alforbir ('euforbio') por 15 libras.

En los años ochenta se documentan en 1480 a los judíos Abrahim Cefín, Jucef Leví, Mordahan Zetén y Jucef Guadix, que vendieron albornoces y otras mercaderías. En 1487 todo el comercio norteafricano tuvo a los tunecinos por protagonistas: Jucef, que trajo 120 s. para comprar y adquirió «verdet» en Valencia; David, se trajo 200 s. para comprar paños (palmilla) y vendió albornoces; Salamó trajo 130 s. para comprar mercancías y vendió otras valoradas en mil sueldos; Salom Masum y Yucef trajeron 2.200 s. para comprar paños; David trajo mil s. para comprar ropas y mercaderías y vendió incienso valorado en 300 s.; Judá trajo 55 s. para comprar mercaderías; Xulim trajo 60 s. para comprar mercancías ${ }^{67}$. El último judío tunecino que se documenta en Valencia es un tal Salom, que compra 280 libras de seda en 1491.

Ocasionalmente, el viaje podía resultar accidentado y el judío verse en serias dificultades, como le sucedió a un tunecino que en 1489 fue apresado por los inquisidores, bajo el pretexto de deber dinero al converso Joan Sisa, condenado por hereje. Cancelada la deuda, pudo conseguir la libertad condicional por intercesión real, como ya hemos visto. Conocemos también el caso de un judío de Túnez, Salamó Zamerón, que estaba al servicio del rey de Aragón, al que el monarca le dio permiso el 23 de julio de 1469 para venir a habitar en Valencia y ejercer su oficio de cordonero $^{68}$.

\section{JUDÍOS DE GRANADA}

A fines de la Edad Media, la población judía del sultanato nazarí se concentraba en las principales ciudades (Málaga, Almería, Baza), además de la propia capital. Su participación en las relaciones comerciales mantenidas entre Granada y Valencia era bastante reducida, dado que este comercio estaba controlado por los mercaderes valencianos y una minoría mudéjar de Valencia ${ }^{69}$.

\footnotetext{
${ }^{67}$ ARV, Maestre Racional, 97, f. ${ }^{\circ}$ 189r y ss.

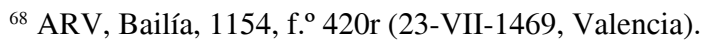

69 J. Hinojosa Montalvo, «Las relaciones entre Valencia y Granada durante la primera mitad del siglo XV», Estudios de Historia de Valencia (Valencia 1978), vol. 1, págs. 91-160; ID., «Las
} 
Entre estos judíos que vinieron a comerciar a Valencia desde el reino nazarí tenemos a Isaac Borgí, al que en 1407 se cita como residente en la ciudad norteafricana de Fez, pero en 1419 aparece ya como oriundo de «les parts d'Espanya», esto es, del reino de Granada. Trajo dos fardos de seda y uno de cera $^{70}$. En 1422 se le menciona como judío de Málaga, donde ya residía su familiar Jacob Borgí.

Otro personaje de esta familia fue Jacob Borgí también afincado en Málaga, que en 1415 trae a Valencia diversas mercaderías ${ }^{71}$. Todo apunta a que era Málaga la ciudad donde residían la mayoría de los judíos que venían a Valencia, pues de aquí era también Jacob Benahim, que en 1415 trajo a Valencia 50 doblas de oro, o Abrahim Cohén, que en 1461 vendió una mora pequeña con sus dos hijos $^{72}$. A la localidad de Sagunto vino en 1457 el granadino Hiaye por cuestión de negocios, marchando luego a Orán, donde fijó su residencia.

La naturaleza de este comercio era similar al que ejercían cristianos y musulmanes, importando a Valencia seda, doblas de oro y productos norteafricanos. Aunque no se indica, cabe pensar que los paños valencianos formaran el grueso de las expediciones de regreso a Granada. Alguno de estos judíos gozó del favor y la protección real frente a las autoridades religiosas, que desde comienzos del siglo XV a menudo molestaban a los judíos con cualquier excusa. Lo vemos en la misiva de Alfonso el Magnánimo dirigida en julio de 1416 al obispo de Valencia porque se había enterado que tenía preso a Samuel de Granada, al que su padre había asegurado por toda la tierra del rey de Aragón. Por ello pedía que le respetara el guiaje y lo entregara a Álvaro de Santa Creu, portero real ${ }^{73}$.

También disfrutaron de la protección real los judíos que vinieron a la corte del

relaciones entre Valencia y Granada durante el siglo xv», en Estudios sobre Málaga y el reino de Granada (Málaga 1988), págs. 83-111; ID., «Armamento de naves y comercio con el reino de Granada a principios del siglo XV», en V coloquio de Historia Medieval de Andalucía (Córdoba 1988), págs. 643-657; ID., «Desplazamientos de mudéjares valencianos entre la gobernación de Orihuela y Granada durante el siglo xv: la ruta legal», Aragón en la Edad Media 14-15 (1999), págs. 743-758; J. E. LÓPEZ DE COCA CASTAÑER, «Los mudéjares valencianos y el reino nazarí de Granada. Propuestas para una investigación», En la España Medieval 3. Estudios en memoria del profesor D. Salvador de Moxó. II (1982), págs. 643-666; M. RUZAFA GARCíA, «Las relaciones económicas entre los mudéjares valencianos y el reino de Granada en el siglo XV», en Relaciones exteriores del reino de Granada. IV Coloquio de Historia Medieval Andaluza. (Almería 1988), págs. 343-382.

${ }^{70}$ ARV, Maestre Racional, 39, f. ${ }^{\circ} 124 r$.

${ }^{71}$ ARV, Maestre Racional, 36, f. ${ }^{\circ} 83 \mathrm{r}$.

${ }^{72}$ ARV, Maestre Racional, 38, f. ${ }^{\text {o }} 83$ r y 71, f. $^{\text {o }} 172$ r.

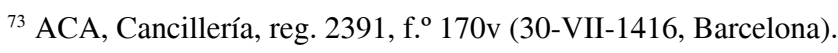


rey de Aragón como mensajeros del rey de Granada, junto con el séquito que los acompañaba. Estos embajadores judíos, que lo eran en buena medida gracias a su conocimiento de la lengua árabe, circularon con alguna frecuencia por tierras valencianas, ya que por aquí pasaba la vía que desde territorio cristiano y a través del reino de Murcia llevaba a Granada. Valencia era también el reino más próximo a Granada y que más vinculaciones tenía con los nazaríes, por lo que en ocasiones se aprovechaba la presencia del monarca en estas tierras para realizar los oportunos contactos diplomáticos, en los que los judíos fueron activos agentes ${ }^{74}$.

En junio de 1427 el judío Jacob Israel recibió un salvoconducto del baile y gobernador general del reino para venir a Valencia como mensajero del rey de Granada a tratar con Alfonso el Magnánimo. Sabemos que el maestre racional le pagó por gastos habidos la suma de $440 \mathrm{~s}$. durante los 80 días que con su familia ha residido en la corte para explicarle el mensaje y recibir respuesta ${ }^{75}$. Hizo el regreso por el camino de Villena, empleando siete días en llegar a esta localidad fronteriza castellana, siendo acompañado para su seguridad por Ferrando Roya, «veguer» de la bailía.

Los viajes no siempre eran por razones mercantiles, sino que los hubo por otros motivos, como los de Mossé Tutor, platero, que en 1431 vino a Valencia acompañado de su hijo ${ }^{76}$. O bien, familiares, como el caso de Magaluf Cabalmale, su hijo Isaac y Jucef Alazyocach se presentaron en diciembre de 1440 ante el baile general del reino para notificarle su llegada a Valencia y solicitar permiso de residencia temporal, a fin de ver a parientes ${ }^{77}$. Por estas fechas había familias Cabalmale en las localidades de Sagunto y Burriana.

Alguno de estos judíos resultó ser cautivo de un cristiano de Valencia, como fue el caso de Alim Alhaig, que en 1421 obtuvo la libertad de su dueño Lleonard d'Aragó, peletero, partiendo el 7 de mayo hacia su lugar de origen. Para hacerlo tuvo que abonar por el derecho del diezmo perteneciente al rey 121 sueldos, así como por la licencia para ir a tierra de moros; otros dos sueldos por el diezmo de las ropas que vestía; nueve sueldos por el derecho de la doble y otros cuatro por el derecho del besante ${ }^{78}$.

${ }^{74}$ R. SAlicrú i Lluch, El sultanat de Granada i la Corona d'Aragó, 1410-1458 (Barcelona 1998).

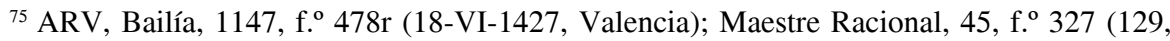
numeración a lápiz).

${ }^{76}$ ARV, Bailía, 267, f. $118 \mathrm{r}-\mathrm{v}$.

${ }^{77}$ ARV, Bailía, 1221, $2^{\text {a }}$ mano, f. ${ }^{\circ} 9$ r (12-XII-1440, Valencia), cit. SALICRÚ I Lluch, El sultanat de Granada i la Corona d'Aragó, págs 373-374.

${ }^{78}$ ARV, Maestre Racional, 41, f. ${ }^{\text {8 }}$ 89r-v. 
A la inversa, tenemos noticias de judíos valencianos cautivos en el reino de Granada, como muestra la correspondencia diplomática del rey de Aragón que en 1428 escribió al rey Muhammad VIII con el fin de que pusiera en libertad a David Bonafé, judío de Aspe, vasallo del noble Eximén Pérez de Corella, que había sido capturado por un moro de Baza llamado Rabaça y sus compañeros cuando entraron a saltear el Reino de Valencia, estando en poder del citado granadino. Rabaça había comprado a sus compañeros la parte correspondiente del cautivo y quería que sus compañeros de presa le devolvieran lo que él les hubiera pagado y que dejaran ir libremente al judío ${ }^{79}$.

JUDÍOS DE ISLAS MEDITERRÁNEAS Y NÁPOLES

\section{Cerdeña}

La isla mantuvo intensos contactos comerciales con Valencia durante el periodo bajomedieval gracias a su inclusión en el espacio político-económico de la Corona de Aragón y en ellos también participaron los judíos ${ }^{80}$, aunque de forma esporádica. Procedían básicamente de Alguer, activo foco catalano-aragonés en la isla. De allí era Abraham Abennazer, alias Daniel, que en 1432 fue robado en el hostal del río de la Cenia, en la frontera con Cataluña, por el converso valenciano Joan de Santafé. Este judío permaneció varios años en Valencia, o al menos regresó a esta ciudad, donde mantenía otros pleitos, pues en agosto de 1435 el baile general del reino se dirigía a todos los oficiales de Castilla certificando que Abennazer, ahora morador en Valencia, como fiador de Roiç Sánxez Barroso, mercader de Valladolid, había hecho diversos pagos a personas de Valencia para que le ayudaran a hacer justicia contra el citado mercader castellano ${ }^{81}$. Todo apunta a que

${ }^{79}$ SAlicrú i Lluch, El sultanat de Granada i la Corona d'Aragó, págs. 227-228.

${ }^{80} \mathrm{~J}$. Hinojosa Montalvo, «Los contactos comerciales entre Valencia y Cerdeña durante el siglo XV», en XIV Congresso di Storia della Corona d'Aragona. La Corona d'Aragona in Italia, s. XIII-XVIII (Sassari 1996), vol. 3, págs. 503-526.

${ }^{81}$ ARV, Bailía, 1148, f. ${ }^{\text {o }}$ 114v (3-VIII-1435, Valencia): como fiador del mercader de Valladolid pagó a Gabriel Vives, mercader de Valencia, 54 1.; a Gabriel Palau, mercader de Valencia, 35 1. y 18 s.; a Joan Fuster, corredor de oreja, 5 1. y 14 s.; a Pagani Rana, mercader de Valencia, 9 1. y 7 s., resto de otra cantidad mayor que Barroso debía a las citadas personas por ropas y mercaderías que les había comprado. Abenazara pagó $50 \mathrm{~s}$. como impuestos a los recaudadores. Otras sumas pagadas en nombre de Roiz Sánchez fueron a Na Joana Sánxex, mujer de Joan Guillem, tornero, 18 s., resto de una suma mayor debida por paño de lino obrado de seda que le compró Sánxez; a Joan Fuster, especiero, 10 s. por medicinas; y a Pere Lenci, mercader florentino, 96 s. por un cambio. 
el judío mantuvo contactos mercantiles de naturaleza que desconocemos con el mercader castellano. Este judío estaba especializado en la ruta Cerdeña-Valencia, pues el 3 de agosto de 1435 obtuvo un salvoconducto del baile general del reino para venir a comerciar a Valencia. Todavía en mayo de 1436 seguía en la capital del reino, pues por entonces la reina María de Aragón, gracias a la intervención del rey de Castilla, recomendaba al citado judío, que pleiteaba con Mayrona, viuda de Vives Mossé, judío de Alguer, al portavoz del gobernador de Cerdeña. En resumen, buenas relaciones con los círculos del poder castellano y pleitos por todas partes, con Joan de Santafé, que le robó; con Sánxez Barroso; y con Mayrona, cuyo resultado ignoramos.

Otro judío procedente de la ciudad sarda fue Abraham Benizmal, al que en 1444 el baile general le dio licencia para regresar a su ciudad, pasando antes por Mallorca.

\section{Sicilia y Malta}

La presencia de judíos sicilianos en el Reino de Valencia fue testimonial, como el siracusano Abrahiç Saragoçí, que el 24 de noviembre de 1402 cedía a Pere de Bordils las deudas que Antoni Ribalt de Valencia tenía con el judío, valoradas en 4 florines. Otro judío de la isla era Abraham Zuçén, oriundo de Trapani, que en 1419 y procedente de Berbería vino a Valencia en la nave del genovés Andrea Doria y vendió seda almeriense ${ }^{82}$.

De Palermo era Angelo de Donar que, en marzo de 1468 vendió una esclava a García Pelegri, mercader, por 47 libras, y otra a Felip Tagores, sedero, por 32, ambas juzgadas «de buena guerra» por el baile general del reino ${ }^{83}$. Otros dos judíos de Palermo que comerciaron con Valencia fueron Abraham, que viene en 1422, 1425, 1431 y 1434, en tanto que Benjamín Haquom lo hace en 1428. Nada nos dice la documentación de los productos y el volumen de este comercio.

En algún caso ignoramos su procedencia concreta, pues el escribano lo anotó como «judío de Sicilia»: es el caso del guiaje concedido en enero de 1426 por el baile general del reino a Isaac Jumenta, judío siciliano, que vino a Valencia al servicio y en la nave de Diego de Orozco, capitán de dicho reino, y que ahora

\footnotetext{
${ }^{82}$ ARV, Maestre Racional, 39, f. ${ }^{\circ} 124 \mathrm{r}$.

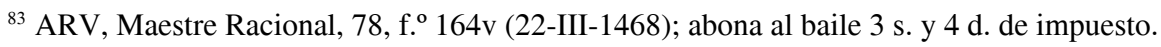


regresaba a Sicilia ${ }^{84}$. Los dos últimos judíos sicilianos que documento en Valencia son del 13 de noviembre de 1481. Se trata de Cala Próspero, que estaba comerciando en nuestra ciudad y lo aprovechó para nombrar procurador a Joan Guanita, notario valenciano, con el objetivo de recuperar las deudas pendientes. Lo mismo hizo ese día León Meresim, siendo en este caso el procurador designado el notario Joan Egidi de Puigmijà. La similitud de fechas, de actos y el recurso al mismo notario hacen pensar que ambos judíos vinieron juntos a Valencia a realizar sus negocios, cuya naturaleza ignoramos.

Las noticias más tempranas de judíos malteses son de septiembre de 1410, en que el lugarteniente del baile general concedió licencia a Cobatey y Salamó, mercaderes judíos de Malta, para que no contrastando cualquier ordenación en contrario, pudieran habitar en Valencia y «fer lur mercaderia»" . Este año también fue autorizado a residir en la ciudad el maltés Salamó. Otro judío que comerció en Valencia en esa década fue Simeón Quete. Ignoramos cualquier aspecto concreto relacionado con este comercio, que sólo aflora en la documentación cuando hay algún problema. Este mismo año, el 10 de octubre, Salamó Faquir y Cebber Meir, judíos de Malta, del reino de Sicilia, fueron condenados por el lezdero de Tortosa -posiblemente por impago de tasas fiscales-, pero luego se presentaron ante el baile general del reino, que anuló la sentencia condenatoria, provocando la protesta del lezdero, que alegaba que el baile no podía entrometerse en su actividad. La respuesta del baile fue justificarse diciendo que su autoridad era superior ${ }^{86}$.

\section{Nápoles}

Mucho menos intenso, el tráfico mercantil entre Valencia y Nápoles tuvo también su reflejo en una menor presencia de judíos de esta ciudad en el reino. Sólo he localizado el 21 de febrero de 1492 a un tal David de Bonaventura napolitano, que reconoció ante el notario deber a Carlo Calvo y a Bernardo Pinillo, genoveses, la suma de 125 ducados de oro, que le había entregado en un cambio. Dicha cantidad se la entregará a Lorenzo Cataneo, mercader genovés en Orán, veinte días después de que la embarcación de Felipo Danenant llegue a esta ciudad norteafricana, sanos y salvos, bajo pena de 50 sueldos $^{87}$. De ello se desprende la ruta viajera de este judío que desde Valencia seguía al norte de África, donde cancelaría su deuda.

\footnotetext{
${ }^{84}$ ARV, Bailía, 1146, f. $337 \mathrm{v}$ (15-I-1426, Valencia).

${ }^{85}$ ARV, Bailía, 1219, f.o 126r (6-IX-1410, Valencia).

${ }^{86}$ ARV, Bailía, 1219, f. ${ }^{\circ}$ 140v (10-X-1410, Valencia).

${ }^{87}$ ARV, Protocolos, n. ${ }^{\circ}$ 2009, f. ${ }^{\circ} 85$ r-v.
} 


\section{Creta}

Nos ha llegado una sola noticia acerca de la presencia de judíos cretenses, correspondiendo a la multa de 15 s. impuesta en 1476 a Bienvenido, judío de Candía, por ir de noche por Valencia sin luz y sin la señal de la rodela ${ }^{88}$.

\section{JUDÍOS DE PROVENZA}

Los judíos que he logrado documentar procedían de la región de Provenza y cuenca del Ródano, siendo Marsella, Arlés y, sobre todo, Aviñón, las localidades que mayor contingente de judíos proporcionan, aunque sus cifras siempre fueron reducidas. Tenemos una noticia interesantísima sobre la presencia de un médico judío aviñonés en el Reino de Valencia, testimonio a su vez de la movilidad del hombre medieval. En 1351 -poco después de la Peste Negra de 1348- en la localidad valenciana de Alcira no había médico, por lo que las autoridades municipales solicitaron al rey que diera permiso para ejercer como galeno a Salomó Astruch de Aviñón que ya residía allí, donde ya ejercía y había realizado «grandes y difíciles» curas. Se trataba por tanto de un médico experimentado y de gran prestigio entre la población local, pero que en el futuro se negaba a ejercer como tal antes de ser examinado por un tribunal, tal como exigían las leyes del reino. De ahí, la petición de los jurados alcireños al rey para que pudiera desempeñar sus funciones médicas, y la licencia dada por Pedro el Ceremonioso el 22 de julio, eximiéndole además del pago de las 10 libras exigidas como tasa de examen ${ }^{89}$.

De Arlés vino a Valencia a comerciar en 1416 «Arlé» y otro judío llamado Bonafostal, que vendía en Valencia trigo y legumbres ${ }^{90}$.

De «Francia» vino en enero de 1410 un judío llamado maestre Samuel, que se hospedó en casa del converso Roger de Montcada. Ignoramos en qué ejercía su maestría, título habitual entre los médicos, además de artesanos altamente cualificados.

Oriundo de Marsella era Durant Maxuni, al que el baile general dio licencia en junio de 1475, junto con Passero d'Avinyó, judío de Aviñón, que vinieron a Valencia a comerciar en las galeazas florentinas, para que pudieran residir en la ciudad el tiempo que la embarcación estuviera surta en el Grao de Valencia.

\footnotetext{
${ }^{88}$ ARV, Maestre Racional, 86, f. ${ }^{\circ}$ 176v (23-XII-1476, Valencia).

${ }^{89}$ ACA, Cancillería, reg. 894, f. ${ }^{\text {29v }}$ (22-VII-1351, Barcelona).

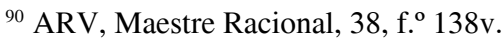




\section{JUDÍOS ALEMANES}

La presencia de judíos alemanes en el Reino de Valencia es tan rara que entre toda la documentación consultada sólo he encontrado un par de noticias al respecto, que hacen referencia a ellos y, en un caso, de manera indirecta. Se trata en primer lugar del salvoconducto concedido el 27 de junio de 1436 por el baile general del reino a «Lión», judío de Alemania, que iba a Cerdeña en la nave de Juan Rapillo, de La Coruña ${ }^{91}$.

El segundo dato es la detención en 1449, a instancia de acusación privada, por el lugarteniente del baile de la localidad castellonense de Alcalá de Chivert de dos judíos que iban sin la preceptiva rodela en sus vestidos. Uno de ellos era de Castellón y fue liberado porque presentó un privilegio real para no llevar la señal distintiva, en tanto que el otro, del que sólo sabemos que era de Alemania, permaneció en prisión ${ }^{92}$.

\section{PROSOPOGRAFÍA DE JUDÍOS EXTRANJEROS EN VALENCIA}

Se excluyen los judíos de Portugal y de Castilla, que figuran en otros trabajos específicos. En las transcripciones de los nombres, que se ordenan por nombre de familia (salvo en aquéllos en los que no se especifica, en cuyo caso se hace según el nombre propio o apodo), y se ha respetado la grafía original.

Aвbez, Jafudá (Argel). En 1439 trajo 15 doblas a Valencia para comprar.

Abenabram, Marduf (Orán). En 1448 vendió en Valencia varios millares de plumas de avestruz (ARV, Maestre Racional, 63, f. ${ }^{\circ}$ 208r).

ABEnCAET, Jucef (Fez). El 5-XII-1407, el baile general le dio un guiaje para reresar a su tierra en la nave armada de Alfonso de Valladolid, marinero de Valencia (ARV, Bailía, 1147, f. ${ }^{\circ}$ 210r).

Abencazuz, Maçot (Tremecén). En 1401 trajo a Valencia desde dicha ciudad norteafricana diversos productos (ARV, Maestre Racional, 20, f. ${ }^{\circ}$ 286v).

Abennacer (o AbenAtZera), Abraham, alias «Daniel» (Alguer). En 1432 trajo a vender a Valencia ropas y mercaderías (ARV, Bailía, 1147, f. o 397v). En 1433 tenía un pleito con Joan de Santafé, acusado de robar al judío en el hostal del río de la Cenia en el reino de Valencia. En 1436 el baile general lo tuvo por recomendado, a instancia del rey de Castilla, en el pleito que mantenía con Roiç Sanxez Barroso, mercader de Valladolid. En 1436 pleiteaba con Mayrona, viuda de Vives Mossé, de Alguer.

Abenvenist, Mahir (Honein). En 1439 trajo nuez de xarch y polvo de orxella.

${ }^{91}$ ARV, Bailía, 1148, f. ${ }^{\text {2 } 251 v}$ (27-VI-1436, Valencia).

${ }^{92}$ ARV, Bailía, 1151, f. ${ }^{\text {}}$ 185r (21-IV-1451, Valencia), ahora publicado en J. R. MAGDALENA Nom DE Déu, «Seis nuevos documentos sobre judíos valencianos (1360-1451)», Boletín de la Sociedad Castellonense de Cultura 81 (2005), págs. 243-250:250.. 
ABrafim (Berbería). En 1466 trajo 80 doblas.

Aвrahim (Túnez). En 1469 vendió polvo de grana e hilo de Almería. Ignoro si se puede identificar con el anterior.

Abram (Palermo). Comerciaba con Valencia en 1422, 1425, 1431 y 1434.

AdDERí, Abrahim (Orán). El baile general le da guiaje el 15-II-1456 para ir a su ciudad, recoger su familia y traerla para residir en Sagunto (ARV, Real, 705, f. 114 (bis) v (suelto).

Alhaig, Alim (Granada). Cautivo de Lleonard d'Aragó, peletero, obtiene la libertad en 1421 y regresa a su país de origen.

AlLón, Magalluf (Berbería). Comercia con Valencia en 1401. En 1409 envía diversos productos a Gabriel Vives, converso de Valencia (ARV, Maestre Racional, 26, f. ${ }^{\circ}$ 249v).

Almalé, David (Berbería). En 1424 envía alheña a Alcudia y Honein desde Valencia.

Almalé (o AlmalhÉ), Isaac (Berbería). En 1409 envía diversos productos a Gabriel Vives, converso de Valencia (ARV, Maestre Racional, 26 f. ${ }^{\circ}$ 249r). En 1410 trae a Valencia 155 cahíces de trigo, cuero, doblas y fideos (ARV, Maestre Racional, 30, f. ${ }^{\circ}$ 244r). En 1414 vendió mercancías valoradas en 1.700 s. (ARV, Maestre Racional, 38, f. ${ }^{\circ}$ 65r).

Almalech, Mossé (Cazaza, en el Reino de Fez). El baile general le da licencia en 1437 para venir a comerciar (ARV, Bailía, 1148, f. 325r).

Almillos (o Almillor), Jafudá (Fez). En 1410 estuvo comerciando en Alicante.

ARGEM, Jucef (Tremecén). Trae a vender a Valencia en 1419 ropas y mercaderías (ARV, Maestre Racional, 39, f. $\left.{ }^{\circ} 124 r\right)$.

Arguet (o Arquet), Abrafim (Orán). Vende en 1413 en Valencia cierta grana (ARV, Maestre Racional, 31, f. . 310r). En 1414 vendió ropas y mercaderías a través de Gabriel Vives, converso y su factor. También trae para vender grana y cueros a Valencia (ARV, Maestre Racional, 38, f. ${ }^{\circ}$ 18r). En 1415 y 1418 vendió a través de su factor Gabriel Vives ropas y mercancías (ARV, Maestre Racional, 38, f. ${ }^{\circ}$ 139r).

ARLÉ (Arles). Documentado comerciando en 1416 en Valencia.

Astruch, Salomó (Aviñón). Reside en 1351 en Alcira donde ejerce como médico.

BaLAiX, Isaac (Túnez). Vende cera por 9 1. y 10 s. en 1476.

BARUCH, Mordofay (Berbería). Trae ropas a vender en 1440 (ARV, Maestre Racional, 56, f. ${ }^{\circ}$ 209r).

Belu, Macluff (Berbería). El 7-V-1464 el baile general concede licencia para desembarcar él, su mujer e hijos, y estar cierto tiempo en Valencia.

Ben Allón, Magaluf (Honein). En enero de 1427 envía desde Honein a Valencia mercancías propiedad de Pons Dezledo, que aseguró Guillem Ceriol.

Ben Halgén, Jucef (Berbería). En 1414, 1415 y 1418 vende en Valencia ropas y mercancías (ARV, Maestre Racional, 38, f. ${ }^{\circ}$ 138r).

BenAhIM, Jacob (Málaga). En 1415 trae a Valencia 50 doblas de oro (ARV, Maestre Racional, 38, f. $\left.^{\circ} 83 r\right)$.

Benatorella, Mossé (Fez). En 1432 trae mercaderías a Valencia (ARV, Bailía, 1147, f. o 397v).

BEngabART, Jacob (Tedeliz). En 1408 el baile general le autoriza a recaudar su rescate.

Benjacob, Samuel (Berbería). En 1418 obtiene licencia del baile general para pasar a tierra de 
moros (ARV, Maestre Racional, 38, f. 63 r).

Benizmal, Abraham (Alguer). En 1444 el baile general le da licencia para regresar a su ciudad, pasando antes por Mallorca (ARV, Bailía, 1149, f. ${ }^{\circ}$ 386r).

Benluba, Jucef (Orán). Citado en 1402, cuando envía desde dicha ciudad diversos productos a Gabriel Ballester y a Pau Maçana, conversos de Valencia (ARV, Maestre Racional, 21, f. ${ }^{\circ}$ $285 \mathrm{v})$.

BenmuÇA, Faraig (Honein). Citado en 1401, 1402 y 1405 en que envió desde Honein a Valencia diversos productos a Gabriel Ballester, converso de Valencia (ARV, Maestre Racional, 20, f. $\left.{ }^{\circ} 285 \mathrm{v}\right)$.

BenmuÇA, Maymó (Mostaganem). Comercia en 1446 en Valencia (ARV, Maestre Racional, 63, f. 208 r).

Bennuno, Çelom (Berbería). En 1415 vende a través de su factor Gabriel Vives ropas y mercancías (ARV, Maestre Racional, 38, f. ${ }^{\circ}$ 139r). Vende en 1416 y 1418 en Valencia ropas y mercaderías, a través de Gabriel Vives, mercader (ARV, Maestre Racional, 38, f. ${ }^{\text {139r). }}$

BiENVENIDo (Candía). Multado en 1476 por ir de noche por Valencia sin luz y sin la señal (ARV, Maestre Racional, 86, f. 176 v).

Bonafostal (Arles). Vende en 1416 en Valencia trigo y legumbres. (ARV, Maestre Racional, 38, f. $\left.{ }^{\circ} 138 \mathrm{v}\right)$.

Bonaventura, David de (Nápoles). Se documenta el 21-II-1492 en el reconocimiento de una deuda a Carlo Calvo y Bernardo Pinelli (ARV, prot. 2009, f. ${ }^{\circ} 85 \mathrm{r}-\mathrm{v}$ ).

Boniva (Honein). Envía en 1402 desde Honein diversos productos a Pau Maçana, converso de Valencia (ARV, Maestre Racional, 20, f. $286 \mathrm{v}$ ).

Borgí, Isaac (Fez). Trae en 1407 junto con David Elsuçí 400 doblas de oro a Valencia. Citado como criado suyo (ARV, Maestre Racional, 25, f. ${ }^{\circ} 171$ r). En 1419 se le cita como procedente de «les parts d'Espanya», esto es, del reino de Granada, adonde quizá hubiera trasladado su residencia. Trajo dos fardos de seda y uno de cera (ARV, Maestre Racional, 39, f. ${ }^{\circ} 124 r$ ). Citado en 1422 como judío de Málaga, donde residía su pariente Jacob Borgí.

Borgi, Jacob (Málaga). Trae en 1415 diversas mercancías a Valencia (ARV, Maestre Racional, 36, f. $\left.^{\circ} 83 r\right)$.

Cabatey (o Cobatey) (Malta). Autorizado en 1410 a venir a Valencia negociar (ARV, Bailía, 1219 , f. $^{\text {1 } 126 r) . ~}$

CAdacQua (Tremecén). En 1437 el baile general le da licencia para venir a comerciar (ARV, Bailía, 1148, f. $326 v)$.

CALEM, rabí (Berbería). En 1476 vendió barraganes y otras ropas por valor de 20 libras. En 1486 se documenta «Alarg Calem» (¿el mismo?), que trajo ropas y barraganes.

CAP, Jucef (Orán). En 1439 trajo 18 libras de seda (ARV, Bailía, 1148, f. o 324v).

CAP, Mossé (Berbería). En abril de 1421 el baile general le dio licencia para pasar a tierra de moros (ARV, Maestre Racional, 41, f. ${ }^{\text {o }}$ 89r).

CAP, Zaull (Bugía). En 1465 vino a Valencia a comerciar, pero fue apresado en el Grao sin razón y llevado a Ibiza, donde fue vendido como cautivo (ARV, Bailía, 1153, f. ${ }^{\circ} 619 \mathrm{v}$ ).

CATHÁn (¿CARHAn?), Israel de (Berbería). En 1486 vendió grana por valor de 42 libras. 
CAXARí, Fahim (Túnez). Envía en 1412 desde Túnez diversos productos a Francesc Pardo, converso de Mallorca en Valencia (ARV, Maestre Racional, 31, f. ${ }^{\circ}$ 310r).

CefFín, Abrahim (Túnez). En 1480 vendió en Valencia albornoces y otras mercaderías.

Cesportes. Ver Sesportes.

Coffén, Jafudá (Mallorca, antes habitante en Orán). En 1416 vendió en Valencia ropas y mercaderías, a través de Galcerà Martí, mercader (ARV, Maestre Racional, 38, f. ${ }^{\circ}$ 139r).

CoHÉN, Abrahim (Málaga). En 1461 vendió una mora pequeña con sus dos hijos (ARV, Maestre Racional, 71, f. ${ }^{\circ}$ 172r).

CohÉn, David (Berbería). Residía en Sagunto, y el 4-III-1452 el baile general le autorizó a ir a Mallorca, en la nave de Joan Callou de Mallorca, a recuperar ciertos bienes que tenía en esa

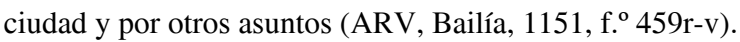

CoHÉn, Mossé (Orán). El 20-IX-1432, junto con Jucef Crespí, fue multado por el baile general por no presentarse ante él (ARV, Maestre Racional, 51, f. ${ }^{\circ}$ 143v).

CREspí, Jucef (Orán). En 1437 el baile general le dio licencia para venir a comerciar a Valencia (ARV, Bailía, 1148, f. 324v). El 20-IX-1432, junto con Mossé Cohen, fue multado por el baile general por no presentarse ante él (ARV, Maestre Racional, 51, f. $\left.{ }^{\circ} 143 \mathrm{v}\right)$.

ÇAнат (Túnez). En 1469 vendió 8 albornoces gruesos por 7 libras.

ÇARAGoçí, Alaig (Berbería). En 1486 vendió un cahíz de trigo.

ÇusÉn. Ver Zuçén.

Daniel (Berbería). En 1486 vendió ropa en Valencia que trajo de su país.

DAVID (Túnez). En 1487 vendió ciertos albornoces por 500 sueldos.

DAVIT (Túnez). Vino a Valencia en 1487 a comprar mercaderías y vendió incienso por valor de 300 sueldos.

DAYTÚN, Abrahim (Berbería). En 1475 vende 150 mazos de plumas de avestruz y 15 albornoces por 60 libras.

DonAR, Angelo (Palermo). El 22-III-1468 vendió dos esclavas (ARV, Maestre Racional, 78, f. ${ }^{\text {o }}$ $164 \mathrm{v})$.

ELsucí. Ver Zuçén.

FARAIG (Túnez). En 1468 trajo 47 doblas de oro para comerciar.

FARAIG, Jafudá (Orán). En 1417 vendió en Valencia ropas y mercaderías, a través de Lluís Soler, mercader (ARV, Maestre Racional, 38, f. ${ }^{\circ}$ 139r).

FARAIG, Isaac (Honein). En 1426 comerciaba con Valencia.

FARAIG, Maymó (Tremecén). Hijo de Abrahim Faraig. En 1466, junto con Judá, trajeron 100 doblas de oro para comerciar en Valencia. Estuvo comerciando en Valencia, a donde vino con galeras venecianas. Manifestó al baile su deseo de residir en la judería de Játiva, en la que se instaló con su familia (ARV, Bailía, 129, f. ${ }^{\circ}$ 167r-v).

FARAIG, Magaluf (Orán). Era factor de Galcerà Martí, mercader de Valencia y en 1426 trajo cebada y trigo (ARV, Bailía, 1146, f. ${ }^{\circ}$ 401r).

Fasvatí, Jesuhé (Argel). En marzo de 1440 Daniel Cornet, mercader de Valencia, aseguró por 70 
libras el transporte de vino y la persona de Fasvati en el viaje a Argel.

FAtuÉn, Samuel. Originario de Mallorca, en 1395 residía en Orán, desde donde envió diversos productos a Valencia.

FAZNÁN, Yuhué (Argel). En 1440 vendió 25 doblas.

FISA, Juan (Túnez). El 24-11-1489 el rey ordenó al baile general que se le pusiera en libertad bajo vigilancia (ARV, Real, 596, f. ${ }^{\circ}$ 65r).

GabAy (Alcudia, Berbería) vendió en 1416 en la ceca de Valencia 30 doblas a través de Gabriel Vives De Berbería. (ARV, Maestre Racional, 38, f. ${ }^{\circ} 139$ r).

GADEs, Magaluf (Túnez). En 1476 vendió 100 mazos de plumas de avestruz y 20 cargas de «orxiqua» por 40 libras.

GALIPAPA, Isaac (Túnez). En 1469 vendió 5 albornoces, 3 libras de «agalla» y dos «barragases».

GALLEGO, Jucef (Tremecén). En 1457 se llevó cardas viejas a su ciudad.

Granada, Samuel de. El 30-7-1416 Alfonso V pide al obispo de para que le respete el guiaje que le concedió Fernando I (ACA, C, reg. 2391, f.o 170v).

GuAdix (o Guindes, Guindix), Jucef (Túnez). En 1468 vendió 9 arrobas de índigo por 24 libras. En 1469 trajo 13 libras para comprar. En 1470 vendió 16 barraganes, 2 albornoces y 3 quintales de sebo. En 1480 vendió albornoces y otras mercaderías en Valencia.

GuEtDEIX, Magaluf (Tremecén). En 1475 vino a Valencia en las galeras venecianas, comerciando con Salamó Zalmatich de Játiva.

Habu, Mossé (Mostaganem). En 1446 vino a comerciar (ARV, Maestre Racional, 61, f. o 170v).

Haquom, Benjamín (Palermo). En 1428 comerciaba en Valencia.

HiAYE (Granada). En 1457 vino a Sagunto por negocios, marchando luego a Orán, donde fijó su residencia.

HoBIDA (Berbería). En 1491 compró en Valencia ropas y mercaderías.

Hylaut, Maholug (Orán). En 1457 se llevó a su ciudad cardas y alambre.

IsRAEL, Jacob (Granada). En 1427 se le documenta como mensajero del sultán de Granada en la corte del rey de Aragón (ARV, Maestre Racional, 45, f. ${ }^{\circ}$ 327).

$\mathrm{J}_{\mathrm{ACOB}}$ (Berbería). En 1466 trajo y vendió ciertas drogas (ARV, Maestre Racional, 76, f. ${ }^{\circ}$ 204r).

ЈАСОВ (Sicilia). En 1486 vendió índigo valorado en 21 libras.

JАСОВ (Trípoli). En 1469 vendió 6 albornoces «sutiles» y un rosario de vidrio por 7 libras (ARV, Bailía, 1154, f. 420 r). En 1470 y 1471 trajo mercancías para comerciar.

JАСOB (Túnez). En 1468 vendió dos quintales de índigo, 3 albornoces y una arroba de almáciga.

JACOB, Abraham (Berbería). Envía en 1406 cera y grana desde Berbería a Nicolau Valldaura, converso de Valencia (ARV, Maestre Racional, 24 f. ${ }^{\circ}$ 171r). En 1415 vendió hilo de Almería (ARV, Maestre Racional, 38, f. ${ }^{\circ} 83 r$ ).

JILICón, Jacob (Berbería). El 8-5-1419, Valencia el baile general le dio licencia para pasar a tierra de moros (ARV, Maestre Racional, 39, f. 72 r). 
JUCEF. (Túnez). En 1471, 1474 y 1487 trajo mercaderías para comerciar en Valencia.

JUDÁ (Trípoli). En 1466, junto con Judá, trajeron 100 doblas de oro para comerciar en Valencia. JudÁ (Túnez). En 1487 vino a Valencia a comerciar.

JumENTA, Isaac (Sicilia). El baile general del reino le concede licencia el 15-I-1426, porque ha venido a esta Ciudad, al servicio y en la nave de Diego de Orosquo, capitán de dicho reino, y que ahora regresa a él.

Leví, Abraham (Argel). En 1467 el baile general le concedió guiaje y aplazamiento de deudas (ARV, Bailía, 1154, f.o 148r).

Leví, Jucef (Túnez). En 1480 vendió albornoces y otras mercaderías en Valencia.

Leví, Mossé. Desconocemos su lugar de origen, aunque debía ser tunecino, pues vino a comerciar a Valencia en 1477 con varios musulmanes de esa ciudad, y vende mercancías por 600 sueldos.

Lión. Judío alemán que en junio de 1436 fue desde Valencia a Cerdeña.

Maçot (o Marzoc), Maymó (Tremecén). En 1425 trae a vender ropas y mercaderías a Valencia.

Magaluf, Faraig (Orán). Factor del converso valenciano Galcerà Martí, relacionándose con otros conversos de Valencia, a los que envía en 1426 trigo y cebada.

Maqualuf (Berbería). En 1474 vendió 15 libras de benjuí y 9 barraganes por 33 libras (ARV, Maestre Racional, 85, f. ${ }^{\circ}$ 207r).

Masum, Salom (Túnez). En 1487 vino a Valencia a comprar ropas.

MaXuni, Durant (Marsella). En 10-VI-1475 el baile general del reino le concede licencia para que pudiera residir en la ciudad el tiempo que las galeras florentinas en las que vino estuvieran en el Grao.

Muça (Trípoli). En 1470 vendió diversas mercaderías (ARV, Maestre Racional, 80, f. ${ }^{\circ}$ 207r).

NADINI (o NADIRI), Samuel (Mostaganem). En 1412 envía desde Mostaganem ciertos productos a Francesc Pardo, converso de Mallorca (ARV, Maestre Racional, 31, f. ${ }^{\circ}$ 18r).

NAGAR, Samuel. Residente en Tremecén en 1412, fue nombrado el 24 de octubre, procurador de Guillem Usall, mercader de Valencia.

Orán, Salamó de (Oriundo de Orán). Se documenta como testigo el 21 de febrero de 1492 en el reconocimiento de una deuda a Carlo Calvo y Bernardo Pinelli (ARV, prot. 2009, f. ${ }^{\text {o }} 85 \mathrm{r}-\mathrm{v}$ ).

PASSERo (Aviñón). En 1475 vino a Valencia a comerciar en las galeazas florentinas.

PAPA (Túnez). En 1470 vendió ciertos productos en Valencia.

QuETÉ, Simeón (Malta). Se documenta en 1416 comerciando en Valencia

Reana (Sijilmasa). Esposa de Salomó ben Annuar, al que Jaime I concedió el 11-VI-1247 su guiaje y cartas de nacionalidad si venían a establecerse en Cataluña, Mallorca y Valencia.

Rimós, Isaac (Mostaganem). En 1412 residía en Orán y mantuvo contactos comerciales con Lluís 
Eximeno, mercader de Valencia, que le envió ciertas mercancías.

Rоввоғ, Abrafim (Berbería). En 1337 fue apresado y vendido como cautivo, alegando que era berberisco, pero los adelantados de la judería de Valencia demostraron que, aunque natural de Fez, vivía en Valencia hacía tiempo con su familia, por lo que el baile ordeno su puesta en libertad.

SABbÁ León, Jacob (Orán). En 1474 Yacob Sabbá León, de Orán, fue autorizado a estar seis meses más y poder vender tres cargas de índigo que trajo ${ }^{93}$.

SALAmó (Malta). Se documenta el 6-IX-1410, en que el baile general le autorizó a residir en Valencia (ARV, Bailía, 1219, f. ${ }^{\circ}$ 126r).

SALAmó (o Salom) (Túnez). En 1487 y 1491 vino a Valencia a comerciar, comprando 280 libras de seda en este último año (ARV, Maestre Racional, 102, f. ${ }^{\circ} 188$ r). En 1492 fue multado por el baile general por cargar bizcocho sin permiso.

SARAGoçí, Abrahiç. El 24-XI-1402 cedió a Pere de Bordils las deudas que Antoni Ribalt, de Valencia, tenía con él, valoradas en 4 florines.

SesPortes, Jucef (Honein). Se documenta en 1405 en que envió desde esta ciudad diversos productos a Gabriel Ballester (ARV, Maestre Racional, 23, f. ${ }^{\circ}$ 165r). En 1409 envió diversos productos a Gabriel Vives (ARV, Maestre Racional, 26 , f. ${ }^{\text {o }} 249 \mathrm{v}$ ).

SibILí, Vidal (Bugía). En 1428 envió fideos a vender a Valencia (ARV, Bailía, 1147, f. ${ }^{\circ} 224$ r).

Suc, Fini (Fez). Vino a Valencia a comerciar y regresó a su ciudad con paños.

Suçí, ver Zuçén.

Sucim. Ver Zuçén.

SuXÉN, Haym (Orán). En 1409 trajo diversos productos desde esta ciudad norteafricana a Valencia (ARV, Maestre Racional, 26, f. ${ }^{\circ}$ 249v).

SUXER. Ver Zuçén.

Tunicí, Abraham (Túnez). En 1470 trae 24 doblas para comerciar.

Tutor, Mossé (Granada). Platero. Viene a Valencia en 1431 acompañado de su hijo por asuntos que aquí tenían (ARV, Bailía, 267, f. ${ }^{\circ}$ 118r-v).

Xulim (Túnez). En 1487 vino a Valencia a comerciar.

Xuxí. Ver Zuçén.

ZaLmatí (Zalmatich, Salmatí, Sarmatich) (Tremecén). Un personaje con este «apellido» fue autorizado el 15-II-1456 para regresar a su ciudad, a fin de traer a su familia para residir en Játiva (Hinojosa Montalvo, La judería de Xàtiva, págs. 49-51).

Zamerón, Salamó (Túnez). En 1469 fue autorizado a ejercer el oficio de cordonero en Valencia (ARV, Maestre Racional, 79, f. ${ }^{\circ}$ 206r).

ZePtim, Abrahim. En 1476 vendió rosarios y plumas de avestruz (ARV, Maestre Racional, 86, f. $206 r$ ).

ZETÉN, Mordahán (Túnez). En 1480 vendió albornoces y otras mercaderías en Valencia.

93 ARV, Bailía, 1296, f. o 61r, cit. J. Hinojosa Montalvo, «Actividades comerciales de los judíos en Valencia (1391-1492)», Saitabi 29 (1979), págs. 35-36. 
ZuçEINs, Hahim (o Fahim) (Berbería). Se documenta en 1405 en que envió diversos productos a Gabriel Vives, converso de Valencia (ARV, Maestre Racional, 23, f. ${ }^{\circ} 165 r$ ).

ZuçÉn (o Çusév), Abraham (Trapani, Sicilia). En 1419 trajo a vender a Valencia ropas y mercaderías (ARV, Maestre Racional, 39, f. $124 r$ ).

Zuçén, Davi (Berbería). En 1407 se cita un David Elxún, que quizá sea este personaje, que vino a comerciar a Valencia con Jucef Abencaet como criado suyo (ARV, Bailía, 1147, f. o 210r). En 1419 trajo a vender a Valencia ropas y mercaderías (ARV, Maestre Racional, 39, f. ${ }^{\circ} 124$ r).

Zuçén, Elvi (o Elsuçi) (Fez/Berbería). En 1417 se le autorizó a regresar a Fez desde Valencia, a donde vino a comerciar. En 1419 trajo a vender a Valencia ropas y mercaderías (ARV, Maestre Racional, 39, f. ${ }^{\circ}$ 124r).

Zuçén (o Sucim, Suxer, Elsuçí, Suçí, Xuxí), Salomón (Honein). Se documenta en 1401 en que envió desde dicha ciudad norteafricana diversos productos a Nicolau Valldaura, converso de Valencia (ARV, Maestre Racional, 20, f. ${ }^{\text { }}$ 286v). En 1405 envió grana a Gabriel Vives, converso valenciano (ARV, Maestre Racional, 23, f. ${ }^{\circ}$ 165r). En 1406 envió desde Honein un saco de algodón a Alí Benxarnit y Caat Ripoll, moros de Valencia (ARV, Maestre Racional, 24 f. ${ }^{\circ}$ 166v). En 1407 trajo con Isaac Borgí 400 doblas de oro (ARV, Maestre Racional, 25 f. $^{\circ}$ 171r). Estuvo en Valencia comerciando en 1409 y 1410.

\section{ANEXO}

1431, febrero, 2, Valencia.

Jucef Franco, de Lisboa, residente en Valencia, confesó ante el notario deber 100 libras a varios mercaderes de Porto, que se las habían prestado, con las que compró diversas mercancías para enviarlas desde Valencia a Lisboa en la barca de Rodrigo Yanyes.

APCCCh, prot. Dionís d'Olit, n. 22037

[Dicta die et anno predicto]

Ego, Jucef Franquo, iudeus mercator civitatis Lisbone, modo vero in civitate Valencie residens, gratis, et cetera, cum presenti publico instrumento, et cetera, confiteor et in veritate recognosco me debere vobis Petro Bernaldes et Egidio Salvadores, et Johanni Yanyes, mercatoribus civibus civitatis del Porto de Portugal, modo Valencie residentibus, presentibus, recipientibus, acceptantibus et vestris centum libris monete regalium Valencie, quas vos michi graciosse mutuastis ad canbium in peccunia numerata et pro canbio de dicta civitate Valencie ad dictam civitatem Lisbone, de quibus centum libris emi diversas mercaturas, hoc est: specyarias, papirum, cotonum et indium, et confita et oppera terre, quas mercaturas onerare debeo in barcha Roderici Yanyes, nuncupata Sent Johan, pro defferendo eas de dicta civitate Valencie ad portum dicte civitatis Lisbone, que mercature et dicte centum libre dicti cambii in ipsis mercaturiis smerciare sunt et existant // ad vestrum et vestrorum riscum, periculum et fortunam de maris et gentium, quousque dicte raube et mercaturie fuerint exonerate de dicta navi in dicta civitate Lisbone cum salvamento unde renuncio scienter omni excepcioni peccunie predicte dictarum centum librarum per vos 
michi non mutuate et per me causa dicti mutui non numerate et a vobis non rabite, non recepte, ut predictur, et doli, et cetera, promitto et fide mea convenio vobis, dictis Petro Bernaldes, Egidio Salvadores et Johanni Yanyes, dictas centum libras vobis aut vestris dare, solvere, contentare et pactare infra tres dies a die qua dicte raube fuerint exonerate cum salvamento de dicta nave in dicta civitate Lisbone ab antea sequentes et continue computandos hoc modo, scilicet, centum decem duplas baladinas sive centum decem coronas auri, bonas et boni ponderi seu precium earumdem, quod precium ipse corone valebit in dicta tercia die de moneta Portogalis omnibus dilacionibus, et cetera. Quod nisi fecero volo pacto speciali, et cetera, in continente lapso dicto termino incidere et incurrere in pena viginti regalium monete Portogalis pro qualibet die que retardavero dare vobis dictas centum libras, ut est dictum. Quequidem pena, et cetera. Et ipsa pena, soluta vel non soluta, et cetera, rato pacto, et cetera, fiat cum exequtoria et fori submissione et renunciacione latissime. Et pro predictis omnibus et singulis, et cetera, sit attendendis, et cetera, obligo vobis et vestris me personaliter et omnia bona et iura mea mobilia, et cetera.

Quod est actum Valencie, et cetera.

Recibido: $24 / 01 / 2008$

Aceptado: $15 / 12 / 2008$ 
